Marquette University

e-Publications@Marquette

$1-1-2013$

\title{
Childish Nonsense? The Value of Interpretation in Plato's Protagoras
}

Franco Trivigno

Marquette University, franco.trivigno@marquette.edu

Published version. Journal of the History of Philosophy, Vol. 51, No. 4 (2013): 509-543. Reprinted with permission by The Johns Hopkins University Press. DOI. (C) 2013 Johns Hopkins University Press. Used with permission. 


\section{Childish Nonsense? The Value of Interpretation in Plato's Protagoras}

F R A N C O V. TR I V I G N O *

IN THE PROTAGORAS, PLATO PRESENTS US WITH A puzzle regarding the value of interpretation. On the one hand, Socrates claims to find several familiar Socratic theses about morality and the human condition in his interpretation of a poem by Simonides (339e-347a). On the other hand, immediately after the interpretation, Socrates castigates the whole task of interpretation as "childish nonsense" appropriate for second-rate drinking parties $\left(347 \mathrm{~d} 5^{-6}\right) .{ }^{\mathrm{I}}$ The core problem is this: taking Socrates's interpretation of Simonides seriously requires undermining the significance of the claims about interpretation, but taking the criticism of interpretation seriously requires undermining the significance of Socrates's interpretation of Simonides. ${ }^{2}$

Broadly speaking, there have been two approaches to this puzzle in the literature. First (this is the most common approach), commentators have simply ignored Socrates's interpretation as philosophically insignificant, since Socrates is being playful and ironic throughout. For example, A. E. Taylor claims that taking the interpretation seriously "ought to be impossible for [anyone] with a sense of humor." In partial defense of his position, Taylor claims that the "professed exegesis . . . is only arrived at by a series of violences done to its language."4 Such commentators simply take the actual interpretation to be playful, ironic and unserious-a parody of sophistic interpretation-and thus to verify Socrates's

I would like to express my gratitude for the generous feedback I received from Theresa Tobin and Ingvild Torsen and for the helpful comments of the anonymous referees.

'All quotations from the Protagoras in translation, with minor alterations, are Lombardo and Bell's in Cooper, Plato: Complete Works, 746-90. For a reading of the dialogue that makes this criticism of interpretation central to its overall purpose, see Griswold "Relying on Your Own Voice."

${ }^{2}$ Scholars who take this puzzle seriously include Frede, "The Impossibility of Perfection"; Pappas, "Socrates' Charitable Treatment"; and McCoy, "Socrates on Simonides."

${ }^{3}$ Taylor, Plato, 256.

4Taylor, Plato, 255.

* Franco V. Trivigno is Associate Professor of Philosophy at Marquette University. 
later claim about interpretation, that it is a childish endeavor. This view comes up against two core objections: first, prior to his interpretation, Socrates insists not only that he knows the poem and has carefully considered it but also that the

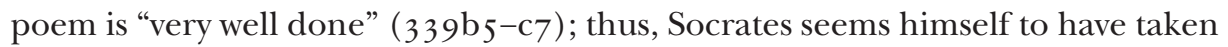
the poem seriously. Second, Socrates uses the poem to defend philosophical claims that he advances both in the Protagoras and elsewhere. In other words, the content of the interpretation squares with Socrates's general philosophical position.

A second, more recent approach takes the interpretation seriously, even while acknowledging that it is arrived at via a blatantly self-serving manipulation of $\mathrm{Si}$ monides's poem. ${ }^{5}$ The passage is said to have philosophical significance insofar as it elaborates a Socratic picture of the human condition. Frede claims that Socrates is serious about "the main points of his own interpretation," but she concedes that he "repeatedly has to distort the text to serve his own purposes." ${ }^{6}$ McCoy argues for the serious nature of the interpretation qua picture of the human condition, but she also concedes that Socrates arrives at it through a series of "deliberate misreadings."7 Part of their motivation seems to be to justify both the section's length and its central position in the dialogue. ${ }^{8}$ Pappas goes further than both Frede and McCoy in attributing to Socrates an interpretive methodology, which amounts to a radical application of the principle of charity, whereby the poet is made to say, on principled grounds, whatever Socrates thinks is true. ${ }^{9}$ This second approach comes up against two objections: First, Socrates is playful and ironic throughout the section and does not seem to be presenting a serious interpretation, much less employing a serious interpretive methodology. Second, taking the interpretation seriously even at this level seems to flatly contradict what Socrates says about the value of interpretation, which he does not say in a playful or ironic manner.

My aim in this paper is to carve out a third alternative. Both positions agree that a series of violences is being done to Simonides's text, but they understand the significance of this in completely different ways. The first approach takes the manipulations to mean that the interpretation is a parody, whereas the second ap-

5Frede, "The Impossibility of Perfection"; McCoy, "Socrates on Simonides." This approach can also be found in Demos, Lyric Quotation, ch. 2.

${ }^{6}$ Frede, "The Impossibility of Perfection," 737.

${ }^{7}$ McCoy, "Socrates on Simonides," 358.

${ }^{8}$ Their strategies for doing so differ substantially. Frede ("The Impossibility of Perfection," 747-49) argues that what she considers the serious part of the interpretation section (343c-347a) was a later interpolation, written around the time that Plato was composing the Symp. This is meant to explain the philosophical sentiments of the interpretation, which resonate with those of the Symp. Her view further explains, or rather explains away, the seeming contrast between the interpretation and the critique of interpretation. On her view, the latter was originally directed at the comic interpretation (339e-343c), which directly preceded the critique in the earlier version. McCoy ("Socrates on Simonides," 349) by contrast wants to preserve the overall unity of the dialogue with the interpretation section as a crucial part of Socrates's larger argument strategy.

'Pappas, "Socrates' Charitable Treatment," 252-59, esp. 256-57. On Donald Davidson's seminal account of the principle of charity (see e.g. "Radical Interpretation"), one seeks to maximize the agreement between oneself and the speakers one interprets. Concerning Socrates's use of this principle, Pappas ("Socrates' Charitable Treatment," 256) claims that "[i]n order to derive true statements from a poem, Socrates is positively compelled to attribute his beliefs to every author." See Scodel, "Literary Interpretation," who also attributes to Socrates an application of the principle of charity, though she and Pappas differ significantly concerning the overall upshot of the passage and Socrates's attitude toward the principle itself. 
proach takes them to mean that Socrates is elaborating his philosophical position through the poem. A common assumption of both positions seems to be that if Socrates's interpretation is a parody, then it can be safely ignored as philosophically insignificant; this implies that if it has philosophical significance, then it is not a parody. ${ }^{\mathrm{T}}$ Advocates of the first approach, satisfied with saying that it is a parody, thus typically ignore Socrates's interpretation, while advocates of the second approach pay attention to Socrates's interpretation but ignore or marginalize the parodic elements. In my view, the passage has philosophical significance because it is a parody. As I have argued elsewhere, Plato uses parody as a critical philosophical tool, which targets certain practices and methodologies, often implicitly relying on an ideal to which the target fails to live up. ${ }^{\text {II }}$ Thus, the mere fact that Socrates parodies the interpretation of poetry does not necessarily mean that he thinks interpretation is a totally useless endeavor. Rather, I argue that Socrates's interpretive manipulations of Simonides's poem articulate parodic criticisms of a certain kind of interpretation, namely, 'sophistic interpretation,' and that this critique implicitly relies on an ideal of interpretation-what I am calling 'philosophical interpretation.' Philosophical interpretation, however, can only partly escape the explicit criticisms of interpretation that Socrates articulates, and it thus only has limited value.

In section I, I provide the methodological context (334c-339a) and articulate Protagoras's model of education, in which the interpretation of poetry stands at the forefront. Then, in section 2, I show how Protagoras's own sophistic interpretation of Simonides's poem (339a-d), what I am calling an 'eristic interpretation,' aims at scoring a victory over both Simonides and Socrates and is supposed to demonstrate Protagoras's superior skill. In section 3, I examine Socrates's interpretation of Simonides's poem (339e-347a), describe its philosophical content, and analyze the parody to reveal the parodic criticisms and the underlying ideal. Socrates parodies both eristic interpretation and a second type of sophistic interpretation, what I am calling 'parasitic interpretation,' which exploits the fame and reputation of the poet in order to justify one's contentions to an audience. As I show, both eristic and parasitic interpretation share an appeal to the authority of the poet, an exploitative and mercenary attitude to the text of the poem, and an indifference to the truth of the claims under discussion. I argue that these criticisms rely on an ideal of interpretation, philosophical interpretation, which remains indifferent to the authority of the poet, attempts a plausible reconstruction of the poem so that a philosophical view is being articulated, and critically assesses and tests this view. $^{\mathrm{I2}}$ In section 4 , I analyze and lay out Socrates's explicit critique of interpreta-

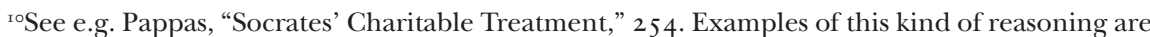
numerous. Vlastos (Plato's Protagoras, xxxiv) claims that Socrates becomes a "practical joker, almost a clown" and does not see any good reason for him to "act out this dubious metaphor in a labored one-man charade." Demos (Lyric Quotation, I I) for her part, claims that the relevant "section of the dialogue, which some consider a comic digression on Plato's part, has a serious intent." The underlying assumption seems to be that the comic and the serious are mutually exclusive: for a clear-headed diagnosis of this mistake, see Silk, Aristophanes and the Definition of Comedy, 3 IO-20.

${ }^{1}$ 'See Trivigno, "The Rhetoric of Parody."

${ }^{12}$ The philosopher, in short, tests the content of the poem to see whether it contains any truth, i.e. mythos is subjected to logos, to borrow a phrase from Halliwell, "The Subjection of Muthos to Logos." 
tion $(347 \mathrm{a}-348 \mathrm{a})$, wherein Socrates castigates the interpreter's failure to use his own voice, the greatest part of which involves testing himself and aiming at the truth. Interpretation is, in short, set against the standard of living philosophical dialectic. In section 5 , I come back to the larger question of the value of interpretation of poetry. I claim that the ideal of philosophical interpretation can only partly escape the explicit criticisms, since it can at best be an imitation of, and provocation for, living philosophical dialectic. It thus only has limited value, and it gets such value from a possible, but contingent, relation to truth. In section 6, I consider an objection to my position, namely, that Plato thinks that paying attention to poetry is, in itself, harmful and thus the idea that interpretation of poetry has even limited value cannot be plausibly attributed to him.

I. THE METHODOLOGICAL DISPUTE: THE PROTAGOREA N MODEL OF EDUCATION (334 C-339A )

Socrates's discussion with Protagoras on the unity of virtue and the nature of goodness grinds to a halt after Socrates successfully shows Protagoras to be committed to a contradiction ( $333 \mathrm{a}-\mathrm{b})$. Protagoras begins to resist answering Socrates's questions $\left(333 b_{3}-4, d I-3, e 2-5\right)$ and then launches into a short speech on the relativity of advantage and disadvantage $(334 \mathrm{a}-\mathrm{c})$. Socrates, claiming to be a "forgetful person" (334c8-9), objects to the length of the speech, insists that Protagoras give short answers to his questions, and twice threatens to leave $(334 \mathrm{c}-335 \mathrm{e})$. After much bickering over how to gauge the appropriate length of an answer and several attempted interventions by the audience to keep the conversation going, a compromise is reached whereby Protagoras and Socrates will take turns questioning each other $(338 \mathrm{e})$.

Protagoras begins by articulating his model of education in which interpretation of poetry stands at the forefront. He claims that the "greatest part of a man's

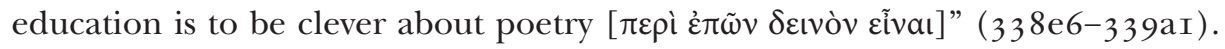
This cleverness encompasses four distinct abilities: (I) to understand what the poet means; (2) to understand what is composed correctly and what is not; (3) to know how to analyze a poem; (4) to know how to give an account in response to questions about the poem. ${ }^{\mathrm{I} 3}$ The interpretation of poetry, on this view, seems to stand on its own as an important skill for any educated person to have. Protagoras's model is not to be lightly dismissed, since assumptions about the wisdom of poets and the important role of memorizing and reciting poetry in moral education were widely shared. ${ }^{\mathrm{I}}$ Given the "widespread and persistent nature of the habit" of "invoking and citing poetic texts to formulate, illustrate, or reinforce a point of view," ${ }^{15}$ what Protagoras offers may be described as advanced lessons in this activ-

${ }^{13}$ Even though neither Protagoras nor Socrates use the Greek term for interpretation, $\varepsilon \rho \mu \varepsilon v \varepsilon v ́ \omega$, in the Prt., I think that I am justified in glossing what Protagoras describes as 'interpretation' because of the close similarities between what Protagoras describes here and what Socrates describes Ion as doing in the Ion (530b-d). In that dialogue, Socrates does mention 'interpretation,' and I see no reason to think that Plato did not mean to implicate the same kind of activity in the Prt.

${ }^{14}$ See Halliwell, "The Subjection of Muthos to Logos," 94-98, for a compelling account of the cultural background against which common practice of poetic citation ought to be understood.

${ }^{15}$ Halliwell, "The Subjection of Muthos to Logos," 95. 
ity, which will enable a speaker to succeed in bringing the poet as a witness for his own view. ${ }^{16}$ Further, whether or not one agrees with Protagoras about the overall value of these abilities, they do seem to present a fairly reasonable picture of the interpretation of poetry. Protagoras's account encompasses both an interpretive and a critical dimension, gives consideration to the poet's intentions, and explicitly leaves room for rational discussion. Having formulated his methodological position, Protagoras endeavors to question Socrates about the very topic they had been discussing, virtue, but "transferred to the context of poetry" (339a4-6). It is at this point that one might be more inclined to object: what does it mean to transfer a topic like virtue to the context of poetry, and is such a move legitimate? It is in light of these larger methodological issues that one must understand both Socrates's parody and critique of interpretation and his subjection of interpretation to the standards of his own rival model of philosophical conversation. ${ }^{17}$

\section{ERISTIC INTERPRETATION: PROTAGORAS A GAINST S I M O N D ES A N D SOCRATES ( 339 A-D )}

Protagoras attempts to demonstrate his skill at interpreting poetry through his own interpretation of Simonides's poem to Scopas. He begins by quoting the first few lines:

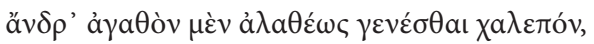

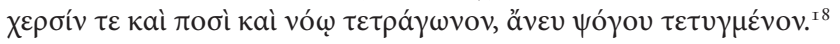

For a man to become good is truly hard

In hands and feet and mind foursquare

Blamelessly built ... (339bI-b3)

He then asks if Socrates needs the sophist to recite the rest for him. This innocent-seeming question can be seen as part of Protagoras's eristic strategy, for he is already testing Socrates's knowledge of the poem and conversely demonstrating his own. Socrates responds that he "knows the poem, and happens to

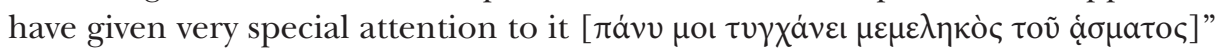
$\left(339 \mathrm{~b}_{5}-6\right)$. As a result of this attention, he claims that the poem "is very well-made

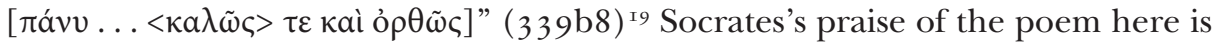
not disingenuous or ironic, nor does his claim to have given special attention to the poem seem to be false.

Protagoras clearly has a competitive agenda, claiming that a poem cannot be

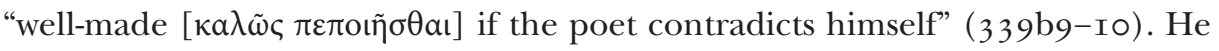
then quotes a line later in the ode:

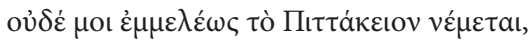

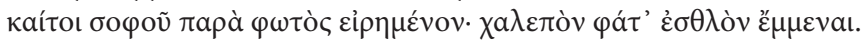

${ }^{16}$ On this practice, see also Aristotle, Met. $995 \mathrm{a} 7-8$.

${ }^{17}$ See Griswold, "Relying on Your Own Voice," $286-87$, on what he describes as the "rivalry of moral ideals" underlying the dispute about education.

${ }^{18}$ All Greek quotations are from Burnet, Platonis Opera, vol. III.

${ }^{19} \mathrm{On}$ the ambiguity of $\kappa \alpha \lambda \tilde{\omega} \varsigma$ and $\mathrm{o} \rho \theta \tilde{\omega} \varsigma$ as adverbial assessments of the quality of poems in the Ion, see Dorter, “The Ion: Plato's Characterization of Art”; Trivigno, "Technê, Inspiration and Comedy.” 
Nor is Pittacus's proverb in tune,

However, wise a man he was.

Hard it is to be good, he said. (339c3-5)

Socrates does not immediately see the contradiction, and Protagoras's interpretation culminates in a short speech, in which he accuses Simonides of saying both that it is, and that it is not, hard to be good ( $339 \mathrm{~d}-\mathrm{e})$. In this passage, Protagoras purports to have demonstrated both that he has the four abilities that constitute cleverness about poetry and that Socrates does not have them. Protagoras seems to understand the poet's words, to analyze the poem, to show that it is not wellmade, and to successfully answer Socrates's question about it, whereas Socrates, by contrast, seems naive about the poem and not to have noticed an obvious contradiction.

I label this kind of interpretation 'eristic interpretation' because it aims at bolstering one's own reputation by showing oneself superior to a figure of reputed wisdom-either the poet under discussion, the person to whom one is speaking, or both. ${ }^{2 \circ}$ By showing a poet like Simonides to be inferior to himself, Protagoras thereby elevates his own public stature. Indeed, Protagoras's interpretation is eristic in both senses, since it is clearly his intention to win fame at the expense of both Simonides and Socrates. At this task, the sophist is quite successful: he gets a round of applause from the audience, and Socrates compares the final move in Protagoras's interpretation-his short speech-to being "hit by a good boxer" $(339 \mathrm{eI}-2) .{ }^{2 \mathrm{I}}$

Even in this short Platonic depiction of sophistic interpretation, we can see some grounds for dissatisfaction. First, there is a clear sense in which Protagoras's interpretation is epideictic - that he is just showing off for the crowd that he is superior to a reputedly wise man. His interest in the poet masks a deeper interest in self-promotion. Second, his attitude toward the text seems mercenary at best. He plucks two passages out of context and shows that they contradict one another. Indeed, as Socrates will show, not only is Protagoras's reading not careful, since the passages do not actually contradict one another, but the larger context also gives information that helps us to see more clearly that there is no contradiction..$^{22}$ Third, Protagoras does not say anything at all about the content of the lines he quotes concerning what it is, or means, to be good. His display is completely indifferent to the robust content of the poem or the truth of the claims about goodness. In transferring the discussion about virtue to the context of poetry, Protagoras has left the content entirely behind.

${ }^{20}$ For the analogy between eristic and wrestling, see Euthd. 277 d. See Aristotle, Poet. I 456bi 5 , in which the first lines of the Iliad are said to have been criticized by Protagoras. This at least suggests that latter engaged in eristic interpretation of poetry fairly frequently.

${ }^{21}$ Woodbury ("Simonides on 'A $2 \varepsilon \tau$,", I 40-4I) calls Protagoras's performance a "tour de force" and rightly points out the contradiction the sophist finds cannot have been obvious to those familiar with the poem.

${ }^{22}$ See Aristotle, Poet. I46 Ia3 I-5; b I 5-I 8 . He formulates an interpretive principle that one should both consider alternative meanings and make every effort to resolve an apparent contradiction in a text. 


\section{THE SOCRATIC PARODY ( $339 \mathrm{E}-347 \mathrm{~A})$}

In this section, I argue that Socrates's interpretation of Simonides parodies two types of sophistic interpretation: eristic and what I am calling 'parasitic interpretation.' A parody is "an imitation which distorts its target, often revealing certain criticisms"; in an earlier article, I argued that the rhetoric of Platonic parody can be seen as complex, in the sense that a parody expresses a criticism while at the same time pointing beyond the criticisms to an implied ideal, which the parodied text fails to live up to. ${ }^{23}$ Thus, the fact that the passage contains a parody does not imply that it should be ignored or passed over as merely comedic. The comedy makes a serious philosophical point.

Frede and McCoy, who want to shine interpretive light on Socrates's interpretation, do so by splitting it up into serious and comic parts, so that the serious content can be gleaned and the comedic parts ignored. Frede, for example, splits up Socrates's interpretation into three sections. The first two sections are, on her view, a "mock display of the sophistic art" (339e-342a) and a "funny ... and fanciful description of the alleged secret conventions of the Spartans" (342a-343c); in her view, the third section $(343 \mathrm{c}-347 \mathrm{a})$ is "different in character and language" than the first two. She essentially ignores the first two parts and concentrates on the "serious" part. ${ }^{24}$ I think such a division runs roughshod over the text, ignoring both the consistently comic tone and the division breaks that Socrates himself signals. ${ }^{25}$ In my view, the passage naturally breaks up into two equally comedic sections: in the first section (339e-342a), Socrates refutes Protagoras's interpretation by engaging in a parody of eristic interpretation using short question and answer. In the second $(342 \mathrm{a}-347 \mathrm{a})$, Socrates parodies what I am calling parasitic interpretation by giving a long speech in which Simonides's poem is made to be about philosophy and to articulate a Socratic picture of the human condition. What Socrates emphatically does not do, in my view, is all of a sudden abandon his comedic performance and begin to interpret the poem in earnest. Indeed,

${ }^{23}$ Trivigno, "The Rhetoric of Parody," 30-32.

${ }^{24}$ Frede, "The Impossibility of Perfection," 739.

${ }^{25}$ Frede's division has three further problems: first, it places a key component of Socrates's supposedly serious interpretation - the difference between being and becoming -in a comedic section (339e-342a), what she calls "a mock display of the sophist's art." Second, her second section $(342 \mathrm{a}-343 \mathrm{c})$ is in a kind of no-man's land and artificially divorced from what she calls the third $(343 \mathrm{c}-347 \mathrm{a})$. These two are clearly bound together by the fact that, in $342 \mathrm{a}-343 \mathrm{c}$, Socrates formulates a thesis about the content and intention of Simonides's poem and, in 343c-347a, he defends it. Third, as Frede herself admits ("The Impossibility of Perfection," 745-46), the last part of Socrates's supposedly serious interpretation $(343 \mathrm{c}-347 \mathrm{a})$, the one affirming the impossibility of voluntarily doing evil (345c-346c), is not serious. McCoy ("Socrates on Simonides," 352-54), perhaps noticing the flaws in Frede's divisions, breaks up the passage into three distinct attempts: the first establishes the being and becoming distinction (339e-34od), the second is "a humorous application of Prodicus' fine distinctions" (340d-34re), and the last contains the core philosophical content (and the passage about the Spartans) (34 I e-347a). On her view, the first and the third attempts elaborate the serious philosophical view, while the second consists mainly in teasing Protagoras and Prodicus and distancing Socrates from the latter's methods (353-54). McCoy's divisions are more sensitive to the text than Frede's, but it seems artificial to break up Socrates's use of Prodicus-inspired distinctions into two attempts, despite Protagoras's forceful objection between them. Thus, I agree with Frede that $339 \mathrm{e}-342 \mathrm{a}$ forms a unit and with McCoy that $342 \mathrm{a}-347 \mathrm{a}$ forms a unit. 
since everyone seems to agree that Socrates distorts the text, it is not clear which aspect of the interpretation is supposed to be serious. ${ }^{26}$

\section{I Socrates's Parody of Eristic Interpretation (339e-342a)}

In the first part of the parody, Socrates beats Protagoras at his own eristic game, while at the same time exposing eristic interpretation as a kind of empty argumentative gymnastics. ${ }^{27}$ Indeed, whereas Protagoras manages to aggrandize himself at the expense of both Socrates and Simonides, Socrates, by allying himself with Simonides, manages to do the same at the expense of Protagoras and Prodicus. Socrates, allegedly dazed by the expert eristic boxing of Protagoras, begins his "rehabilitation" of Simonides by calling on Prodicus and his famous distinction-

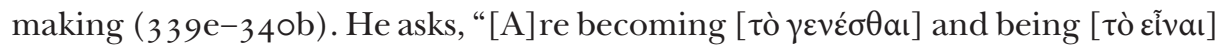
the same or different?" (340b4-5). Prodicus's emphatic affirmative indicates that the question is embarrassingly easy, and Socrates proceeds rightly to point out that

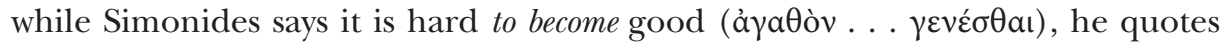
Pittacus as saying that it is hard to be good ( $\dot{\varepsilon} \sigma \theta \lambda$ òv $\left.\varepsilon^{\prime} \mu \mu \varepsilon v a\right) .{ }^{28}$ This is a striking blow against Protagoras, who would have clearly been expected to know and to recognize the distinction. However, as several scholars have noticed, Simonides's own usage of these terms in the rest of the poem belies the idea that the poet has a strict distinction in mind between being and becoming. ${ }^{29}$ When Socrates suggests that Simonides agrees with Hesiod's claim that goodness is difficult ( $\chi \propto \lambda \varepsilon \pi \eta \dot{v}$ ) to acquire but easy ( $\dot{\rho} \eta \ddot{\delta} \delta i ́ \eta v)$ once one has attained it (340c8-d 5), Prodicus applauds,

${ }^{26}$ At minimum, the interpretation is serious in the sense of pertaining to and expressing important moral claims. Most agree that Socrates's interpretation is not serious in the sense of being an honest interpretation of Simonides, but there has been wide and longstanding disagreement over the original meaning of the poem, including whether it has any ethical implications whatsoever; see Parry, "An Interpretation of Simonides 4 (Diehl)," 298-304, for various possibilities. A subset of scholars, including Frede ("The Impossibility of Perfection," 737) and Demos (Lyric Quotation, I I), thinks that Socrates's interpretation is broadly correct as well: see also e.g. Donlan, "Simonides Fr. $4 \mathrm{~d}$ and P. Oxy. 2432"; Babut, "Simonide Moraliste." But even if this is true, surely it matters a great deal how one comes to the right interpretation, just as it matters to Socrates a great deal how one comes to the truth. The latter methodological point about inquiry is surely relevant and becomes explicitly so in Socrates's critique of interpretation. Given the manner in which Socrates arrives at his interpretation, it does not matter that much whether or not Socrates's interpretation is correct in some sense.

${ }^{27}$ Demos (Lyric Quotation, I4) refers to this exchange as "an agōn in which Socrates is intent upon demonstrating that Protagoras is not as keen a literary critic (or one who ranks himself as sophos as the poets) as he himself thinks." Demos is surely right to see this passage as an agōn, but that it is no way incompatible with it also being a parody. Indeed, the parodic aspect provides the agōn with the necessary critical perspective by which the task of interpretation is exposed as useless. Further, if Socrates's purpose were merely to show that he can beat Protagoras at his own game, it is hard to see why he continues with his interpretation even after he has defeated the latter in the eristic section. For a similar criticism of the idea, espoused in Barney, "Socrates Agonistes: The Case of the Cratylus Etymologies," $85-88$, that being an agōn is incompatible with being a parody, see Trivigno, "Etymology and the Power of Names."

${ }^{28}{ }_{\varepsilon} \mu \mu \varepsilon v a$ is an Epic form: see LSJ, s.v. عi $\mu$. It is worth noting that Socrates might have called upon

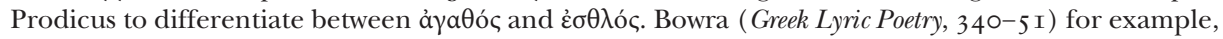
makes his own interpretation of the poem turn on a difference between these terms, as does Woodbury,

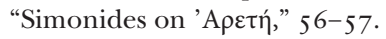

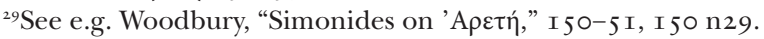


but Protagoras goes on the attack. It is worth noting that, as we will see, Socrates does not really think that Simonides agrees with Hesiod at all. ${ }^{\circ}$

Protagoras continues his eristic assault on both Simonides and Socrates by claiming that Socrates's rehabilitation "has a crippling error greater than the one [he] is correcting" and that Simonides's ignorance "would be monumental if he

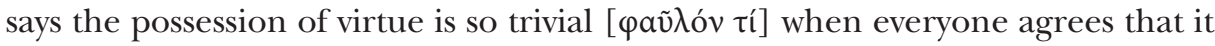
is the hardest thing [ $\left.\chi \alpha \lambda \varepsilon \pi \omega \tau^{2} \alpha \tau o v\right]$ in the world" (34od7-8, e 5-7). Protagoras here commits a fallacy of equivocation, taking the opposite of 'hard' to be 'trivial'

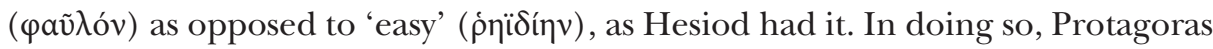
attempts to reclaim his victory over Socrates and Simonides by appealing to common opinion, ${ }^{3 \mathrm{I}}$ while at the same time defeating an arguably greater foe, Hesiod. Again, we see Protagoras using an implausible and self-serving interpretation of the text, this time of Hesiod, to make himself seem grander. And again, we see Protagoras failing to reflect in any way on the content of his claims, making it seems like virtue is valuable because it is difficult to acquire.

In response, Socrates shifts allegiances in the eristic game, by calling on Prodicus again, but this time inducing him to say something ridiculous, to which Protagoras rightly objects. At the same time, Socrates manages both openly and subtly to insult Protagoras and indirectly to suggest that the interpretation of poetry, as Protagoras conceives of it, is worth nothing. Socrates, claiming that Prodicus's wisdom is beyond Protagoras, suggests that Simonides meant something different by 'hard' ( $\chi \alpha \lambda \varepsilon \pi$ òv) than what Protagoras understands. In explaining

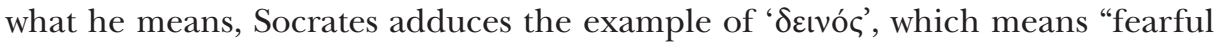
and terrible," "strong and powerful" and "skillful and clever." ${ }^{2}$ He claims that Prodicus has chided him for using ' $\delta \varepsilon v v$ ć ' to praise another, as in "Protagoras is a

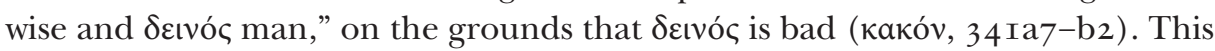
example cuts in multiple directions. First, the value of arbitrarily restricting the semantic scope of ' $\delta \varepsilon v$ ó $\varsigma$ ' is called into question, and with it, the usefulness of Prodicus's art. ${ }^{33}$ Second, Socrates subtly suggests that Protagoras is in fact $\delta \varepsilon \imath$ ó

${ }^{30}$ Socrates paraphrases Hesiod, Works and Days, 289, 29I-92. Another poem of Simonides, PMG 579, in Page, Poetae Melici Graeci, contains the very similar image of virtue on the top of a steep cliff, which may very well refer directly to Hesiod. It is not clear from the fragment whether Simonides is endorsing the claim or not: he begins with "there is a story," but we do not have Simonides's judgment on the story.

${ }^{31}$ In the Great Speech (320c-328d), we see Protagoras employing the strategy of appealing to common opinion throughout: see e.g. $323 \mathrm{~d} 5^{-8}$; a 5-7. This appeal to common opinion is legitimate, in part because, on his view, everyone possesses political virtue (see esp. $322 \mathrm{~d}-323 \mathrm{a}$ ). The connection between Protagoras's own strategy and Socrates's later attribution of the views leading up to the formulation of the hedonic calculus to "the many" may lend indirect support to those who consider Socrates to be there elaborating a Protagorean as opposed to a Socratic view.

${ }^{32}$ See LSJ, s.v.

${ }^{33}$ McCoy ("Socrates on Simonides," 353) suggests that one problem with Prodicus's method is that it "affixes fixed, precise meanings to words without attention to their context" (my emphasis). This is right on target, in my view, for it is not at all clear what is achieved by such distinctions from a philosophical perspective. Indeed, the Cratylus, in which Prodicus is referenced as an expert on the correctness of names $(384 \mathrm{~b})$, can be seen as making precisely this point against etymology: on this possibility, see Trivigno, "Etymology and the Power of Names." Through the exercise of his art in the Protagoras, Prodicus is made to look foolish and utterly incapable of distinguishing meanings. That Prodicus is obsessed with distinction making as a methodology is presumably part of the intention 
in the bad sense, that he is a dangerous opponent to philosophy and to the life of genuine virtue. Third, recall that Protagoras made being ' $\delta \varepsilon เ v$ ć' (translated above as "clever") about poetry a core component of education. The suggestion is that this skill is also bad. Indeed, ' $\delta \varepsilon \imath$ ó, ,' like 'clever' in English usage, contains an ambiguous estimation of an alleged skill. ${ }^{34}$ More broadly, one also should recall that Hippocrates, when pressed, pinned down Protagoras's alleged expertise as

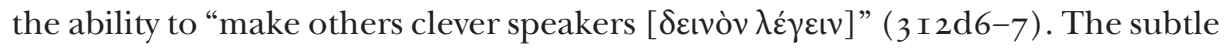
implication here is, thus, that not only are Protagoras and his skills bad, but that he will make others bad as well. ${ }^{35}$

Prodicus, perhaps flattered by Socrates's ironic praise, takes the bait and asserts that Simonides means "bad" (какóv) when he says 'hard' ( $\chi a \lambda \varepsilon \pi$ òv). Simonides is thus made to censure Pittacus for saying something absurd, that it is bad to be good. In fact, Prodicus understands Simonides to be censuring Pittacus for failing to distinguish words properly (34Ic6-9). That is, Prodicus understands Simonides to be concerned with his own area of expertise, a theme I will come back to in the second part of the parody. Protagoras is incredulous, and rightly so. Indeed, an absurd implication of Socrates's reconceptualizing of "hard" would be that the poet himself would be saying in his own voice that becoming good is bad, a claim hardly less outrageous than what Pittacus is made to say. In response to Protagoras, Socrates joins forces with the sophist and abandons Prodicus, claiming that the latter was "only joking" and "trying to test [Protagoras's] ability to defend his own account" (34Id6-9). Socrates proceeds to prove that Simonides did not mean "bad" by 'hard' by quoting the next line of the poem: "God alone can have this privilege" (34 I 3 ). Socrates's introduction of this line has several implications. First, Prodicus must be wrong, since Simonides is shown to mean that it is not merely hard but impossible for a human being to be good and remain that way indefinitely. To become good temporarily is, on this reading, hard but possible. Second, Protagoras's objection is now answered, since virtue is the province of the gods and hardly a trivial matter. Third, Simonides's position is now set in opposition to Hesiod's claim as well. Socrates thus ups the ante on the eristic dynamics of the debate and scores a victory over both Protagoras and Prodicus.

Socrates surely wins, but what has he won? Through a series of shifting allegiances both to persons (Simonides, Hesiod, Protagoras, and Prodicus) and to claims (Simonides agrees with Hesiod, Simonides means "bad" when he says 'hard'), he has scored victories at the expense of Protagoras and Prodicus. ${ }^{36} \mathrm{He}$

of the depiction of Prodicus's short speech in which he makes four distinctions in rapid succession: impartially and equally; debate and eristics; respect and praise; being cheered and being pleased $(337 \mathrm{a}-\mathrm{c})$. It is surely part of the joke at Prodicus's expense that, when Socrates and Hippocrates arrive, they find him still in bed wrapped up in several blankets while his booming voice caused an echo that "blurred what was being said" (3 I9aI-2).

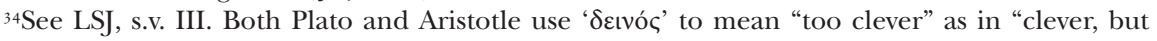
lacking real content or value."

${ }^{35}$ In questioning Hippocrates about his eagerness to become Protagoras's pupil, it becomes quickly clear to Socrates that the boy has no clear idea what he is getting himself into. Socrates rebukes him in the strongest terms for risking his most precious possession, his soul, by entrusting it to a sophistwithout knowing what a sophist is—and to the sophists' teachings—without knowing whether these are harmful or beneficial (3I3a-3I4c).

${ }^{36}$ Frede ("The Impossibility of Perfection," 736ni9) describes Socrates treatment of the two sophists as "naughty." 
operates by setting argumentative traps for both Protagoras and Prodicus and thus can be said to be arguing in bad faith. Indeed, his parody of eristic interpretation has exactly the same faults as Protagoras's more serious version. First, like Protagoras's interpretation, Socrates's parody is epideictic, showing that he is superior to Protagoras and Prodicus, reputedly wise men, at their own games. Second, like Protagoras, Socrates's attitude toward the text seems mercenary, despite the fact that he uses the text as a way to defend its author. He too plucks passages out of context and suggests ways of understanding the text that he himself is not committed to. Indeed, Socrates makes claims about the text that very quickly he rescinds. He merely uses the text to his own advantage in the eristic game against the two sophists. Thus, while it may seem like a minimal principle of charity is operative here, Socrates is employing no such thing. Third, like Protagoras, Socrates does not say anything at all about the content of the lines he quotes concerning what it is, or means, to be good. No positive view on the nature of virtue has been advanced or defended. All we know is that Simonides, Pittacus, and Hesiod have three different views on the matter. Further, Socrates goes beyond Protagoras in refusing even to pretend to be serious about the details of his interpretation. While Protagoras earns a hearty round of applause, Socrates is met with silence. By exposing the eristic game in this way, he is ruining it for everyone.

\subsection{Socrates's Parody of Parasitic Interpretation (342a-347a)}

In the second part of the parody, Socrates attacks a different sort of sophistic interpretation-what I call parasitic interpretation-which uses the fame of the poem as an implicit premise in an argumentum ad verecundiam, an argument from authority. While eristic interpretation might have been something reserved for specialist sophists, parasitic interpretation was a strategy of argumentation in much wider use. ${ }^{37}$ Socrates first presents his hypothesis about the poem $(342 \mathrm{a}-343 \mathrm{C})$, namely, that Simonides's purpose is to win philosophical fame by deliberately attacking Pittacus's famous maxim; he then articulates what is essentially the Socratic philosophical position through a tortured reading of the text of the poem $(343 \mathrm{c}-347 \mathrm{a})$. Socrates gives a very long speech, thereby temporarily abandoning his own methodological commitment to question and answer and the agreed upon procedure with Protagoras.

In formulating his hypothesis about Simonides's poem, Socrates puts philosophy front and center. Indeed, the very first word Socrates uses in his explanation of the ode is 'philosophy' (342a7), and in articulating his hypothesis, Socrates suggests that the Spartans harbor a secret cult of philosophers and that their superiority to the world consists in their wisdom, a fact that they are very anxious to conceal $(342 a 7-d 4)$. Their anxiety to hide the genuine source of their superiority accounts for Spartans having exactly the opposite reputation: unsophisticated warriors who are obsessed with exercising and have cauliflower ears from wrestling too much. The particularly Spartan mode of philosophical expression consists of "pithy, memorable sayings," and Socrates even goes so far as to attribute the inscriptions

${ }^{37}$ See Halliwell, "The Subjection of Muthos to Logos," 94-98. 
on the oracle at Delphi to them (343a7-b3). As Socrates puts it, the "characteristic style of ancient philosophy was laconic brevity" (343b4-5), and one must see Pittacus's saying as falling within this tradition. Socrates's thesis about the poem is that Simonides had the intention of refuting Pittacus in composing his poem, comparing the poet to a wrestler trying to beat the best: ambitious for philosophical fame, Simonides attacked a well-known saying from a reputedly wise man.

There are several things to notice in Socrates's presentation of his hypothesis. First, Socrates makes the poem out to be about philosophy, his own area of proficiency, and indeed makes Simonides out to be a practitioner of the elenchus (see $344 b_{3}-5$ for an explicit reference). This is no different from Prodicus's earlier claim that the poem is about the precise use of words. While Prodicus's claim may have been equally implausible, the elaborate back story about the secret Spartan cults to which Socrates resorts makes his suggestion more ludicrous. Recall too that Protagoras had claimed that a whole host of reputed wise men from the past were secretly sophists: poets like Homer, Hesiod, and Simonides; cult religious figures, like Orpheus and Musaeus; musicians, like Agathocles and Pythoclides; and even athletes, like Iccus and Herodicus (3I6c-e). In claiming Simonides for philosophy, Socrates can be seen as both rejecting and mocking Protagoras's claim. Second, in the course of describing philosophical style, Socrates attributes his own methodological preference for brevity of expression to the ancients, even while he is in the process of giving a long speech. Third, the tone of this passage is clearly comic and thus sets the stage for the comedic defense of the thesis the passage formulates. Contra Frede, there is no sense in which we find a tone shift at this juncture from comic playfulness to serious philology, or to serious philosophy for that matter.

In defending this hypothesis about Simonides's intention in writing the poem $(343 \mathrm{c}-347 \mathrm{a})$, Socrates articulates a Socratic picture of the human condition. Frede, summing up Socrates's "serious" interpretation, finds no fewer than four core Socratic theses:

Socrates' interpretation of Simonides' poem contains (even if it is achieved by hook or crook) some serious Socratic/Platonic tenets: (I) that man never is good but only becomes good (i.e. temporarily), (2) that therefore a median state must be regarded as acceptable, (3) that virtue is knowledge and the only real disaster is its loss, (4) that no-one does evil voluntarily. (Frede, "The Impossibility of Perfection," 746)

My aim here is not to deny that Socrates uses Simonides's poem to articulate these four Socratic claims. Nor is my aim merely to show that Socrates distorts the text in order to do so, since Frede, McCoy, and Pappas all agree that Socrates does this. Rather, I want to argue that the distortions can be understood as part of a parodic strategy, whereby Socrates implicitly criticizes parasitic interpretation. If this is in fact what Socrates does in his interpretation, since we know that he does not consider the poets to be moral experts, we can safely conclude that the interpretation is a parody. Socrates's parasitic interpretation breaks up into five parts: an introduction (343c-344a); the articulation of the claim that "man never is good but only becomes good" (344b-344e); the articulation of the claim that "virtue is knowledge and the only real disaster is its loss" $(344 \mathrm{e}-345 \mathrm{C})$; the articulation of the claim that "no-one does evil voluntarily" (345c-346c); and the articulation 
of the claim that "a median state must be regarded as acceptable" $(346 \mathrm{c}-347 \mathrm{e})$.

First, in order to set up his reading, Socrates provides a tortured reading of the first line of Simonides's poem:

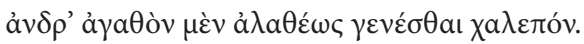

It is hard to become a man truly good. (339bI)

He first reads the $\mu \dot{\varepsilon} v$ as anticipating a contrast with Pittacus's maxim, indeed, as being nonsensical unless it anticipates such a contrast (343c7-d6). Since we do not have the lines between the first few and the reference to Pittacus, we do not know what the $\mu \dot{\varepsilon} v$ might have actually contrasted in the poem..${ }^{8}$ In fact, the $\mu \dot{\varepsilon} v$ need not anticipate a contrast at all. ${ }^{39}$ Socrates proceeds as though there were no intervening lines, looks for a contrasting $\delta \dot{\varepsilon}$, and finds one introducing Pittacus's maxim (oủ $\delta$ '). Not only is it very unlikely that the contrasting $\delta \dot{\varepsilon}$ would come seven lines later, it is very unusual for $\mu \varepsilon \dot{v}$ to anticipate oủ $\delta \varepsilon^{4} .^{\circ}$ Socrates's move here is meant to show that the intention to criticize Pittacus is present in the very first line and shapes the entire poem. His next move is puzzling. Socrates claims that the placement of $\dot{\alpha} \lambda \alpha \theta \dot{\varepsilon} \omega \varsigma$ is a case of hyperbaton and proceeds to understand the "truly" as modifying "hard" as opposed to "good," on the grounds that "it would be silly and unworthy of Simonides" to suggest a difference between genuine and false goods (343e2); rather, Simonides must be understood as saying that becoming good is truly difficult. On Socrates's placement, the "truly" supposedly anticipates a contrast with Pittacus, thereby confirming his overall view. This is clearly an implausible reading of the line, given the natural sense dictated by the word order and the fact that the poem then elaborates what 'truly good' means in the next line..$^{\mathrm{I}} \mathrm{It}$ is particularly bizarre since Socrates is perfectly happy in other places to draw a distinction between genuine and seeming goodness. ${ }^{42}$ But if the contrast between genuine and seeming goodness is what Simonides has in mind, then the $\mu \dot{\varepsilon} \nu$ was likely answered by a $\delta \dot{\varepsilon}$ connected to seeming good. ${ }^{43}$ This would undermine the idea that Simonides has Pittacus in mind throughout. ${ }^{44}$ Thus, Socrates could not conclude his introduction with the claim that "the overall struc-

${ }^{38}$ According to long-standing scholarly consensus, the original poem consisted of four stanzas, with ten lines each, and the lines quoted at $339 \mathrm{bI}-3$ are the first three lines of the first stanza, of which the rest is missing. The lines referring to Pittacus are thought to be the first lines of the second stanza, which is nearly complete. See Taylor, Plato: Protagoras, I42; Donlan, "Simonides Fr. 4d and P. Oxy. 2432," 69. Thus, on this reconstruction of the poem, the contrasted $\delta \dot{\varepsilon}$, if there was one, was likely to be found in the first stanza (Donlan, "Simonides Fr. 4d and P. Oxy. 2432," 8I). However, Beresford ("Nobody's Perfect") has proposed a new arrangement of the text of the poem, whereby it has only three stanzas of ten lines each. The upshot of the view is that the entirety of the poem can be found in the Prt. Denyer (Plato: Protagoras, I47-48) has followed suit. Even if Beresford ("Nobody's Perfect," $242-43$ ) is right about his reconstruction, the initial $\mu \varepsilon \dot{v} v$ still does not look all the way forward to a contrast with Pittacus's maxim. Either way, Socrates is forcing the $\mu \varepsilon \dot{v}$ to do something it is not in fact doing in the poem.

${ }^{39}$ There is an emphatic use: see Denniston, The Greek Particles, s.v. $\mu \varepsilon \dot{v}$ I.

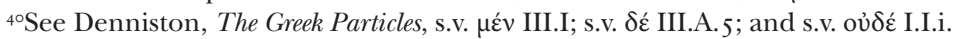

${ }^{4}$ Demos, Lyric Quotation, 22.

${ }^{42}$ See Frede, "The Impossibility of Perfection," 74I.

${ }^{43}$ See Donlan, "Simonides Fr. 4d and P. Oxy. 2432," 8O-8I.

${ }^{44}$ If Simonides has anyone in mind throughout, it is likely Scopas, the actual addressee of the poem. Bowra ("Simonides and Scopas," 232) speculates that the first stanza contained a direct reference to Scopas: see also Parry ("An Interpretation of Simonides 4 (Diehl)," 298), who sees the poem 
ture and intention of the ode ... is from beginning to end a refutation [elenchus] of Pittacus's maxim" (344b3-5). Socrates has managed to turn Simonides into a kind of Socratic philosopher, one who refutes the claims of others. In doing so, he provides an authoritative source to justify his own activity.

In the second part (344b-344e), Socrates asks us to imagine that Simonides is making a speech to Pittacus, insisting that to become good is hard but possible for a brief time, while to be good is impossible for human beings-only possible for the gods. While this sentiment, in its perfectly general form, may have been shared by Simonides and Socrates, Socrates understands goodness and virtue strictly in terms of knowledge. Indeed, the assumption that virtue is knowledge colors Socrates's interpretation throughout. He gives the good man, in Frede's words, a "decidedly Socratic character." 45 Indeed, for the rest of the interpretation, we see Socrates bypassing a more natural understanding of Simonides's meaning for one that suits his own view. In interpreting the next lines of the poem, Socrates introduces his famous technē analogy:

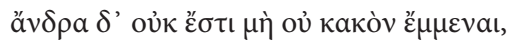

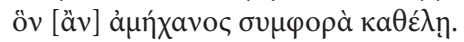

But that man inevitably is bad

whom irresistible misfortune throws down. $(344 \mathrm{c} 4-5)$

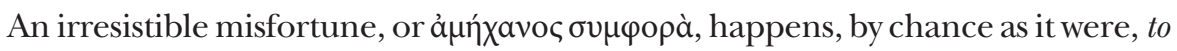
someone. ${ }^{46}$ In asking whom such a misfortune could possibly throw down, Socrates

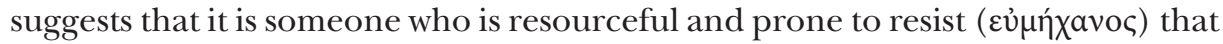
is thrown down. He adduces the examples of the pilot, the farmer, and the doctor, all analogues to the good man by virtue of their possession of craft-knowledge, or techne.

In the third part (344e-345c), Socrates quotes Simonides again, as though the poet were continuing his refutation of Pittacus:

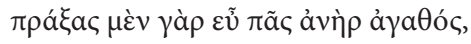

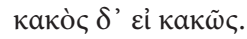

Faring well, every man is good.

Bad, faring ill. (344e $7-8)$

Socrates approaches this line by asking, "what does it mean to fare well in letters; what makes a man good at them?" (345aI-2). His answer, "clearly the learning of letters," leads him to the conclusion that the only "real kind of faring ill is the

as a consolation to Scopas for "some specific disappointment about which we know nothing." The practice of writing poems for wealthy and distinguished gentlemen simply did not permit criticisms of any kind. Indeed, praise would have been much more likely, and it has even been suggested that the poem is an encomium to Scopas: see Dickie, "The Argument and Form of Simonides 542 PMG," 2I-22, 32-33. Regarding Simonides's purpose, Smyth (Greek Melic Poets, 3 I I-I2) goes so far as to restrict the possibilities thus: " $[\mathrm{I}] \mathrm{t}$ is uncertain whether the poet is endeavoring to free Scopas from an accusation based on some specific act of injustice, or to furnish him with an ethical code that may excuse a persistent policy of oppression."

${ }^{45}$ Frede, "The Impossibility of Perfection," 74I.

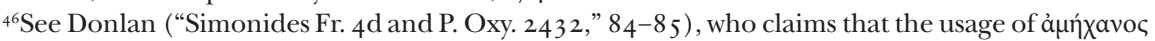
"always signifies someone or something against which or over which the subject has no resource or control." 
loss of knowledge" that comes through sickness, old age, etc. (345a2, b5). This move clarifies both what it means to be bad-to be ignorant-and what sort of irresistible misfortunes cause the loss of knowledge. On this account, to be a good man would involve being fully insulated from such circumstances that cause the loss of knowledge, and this is only possible for the gods. Though the sentiment here is clearly Socratic, ${ }^{47}$ the connection to Simonides's poem is tenuous at best.

In the fourth part $(345 \mathrm{c}-346 \mathrm{c})$, after quoting without comment a passage where Simonides rejects the quest for a blameless man (see discussion below), he quotes another section of the poem:

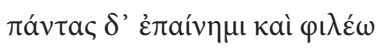

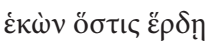

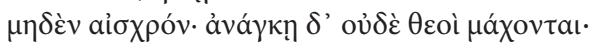

All who do no wrong willingly

I praise and love.

Necessity not even the gods can resist. $\left(345 \mathrm{~d}_{3}-5\right)$

Socrates takes this line to imply that no-one does wrong willingly, even though Simonides seems implicitly to allow for the possibility; by praising those who do no wrong willingly, he surely makes the willing commission of both right and wrong actions possible. This section contains the most egregious misreading, and even Frede admits that this section is "the least serious" and that "it is out of the question that Simonides shared Socrates' enlightened view." ${ }^{8}$ Socrates, contra Frede, seems certain not only that Simonides held this view, but that it was widely held by wise men generally:

Simonides was not so uneducated as to say that he praised all who did nothing bad willingly, as if there were anyone who willingly did bad things. I am pretty sure that none of the wise men thinks that any human being willingly makes mistakes or willingly does anything wrong or bad. They know very well that anyone who does anything wrong or bad does so involuntarily. (345d6-e4)

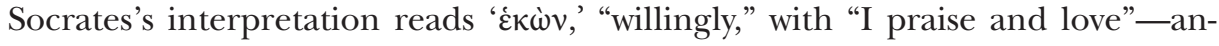
other instance of hyperbaton-so that Simonides willingly praises those who do no wrong. ${ }^{49}$ Again, there is no question of this being a serious interpretation, in the sense of being an honest account of what the poem might plausibly mean. Socrates simply imposes his own views on the text. Indeed, Socrates takes the opportunity to take a partial swipe at Simonides for writing so many poems in praise of tyrants $(346 \mathrm{~b}-\mathrm{c})$. Notice here too that the appeal to authority is overt. All wise men, including Simonides, share Socrates's view on the impossibility of willingly doing wrong; therefore, it must be true. Socrates does not even pretend to argue for the position.

${ }^{47}$ For the problem posed by the loss of knowledge, see Symp. $207 \mathrm{e}-208 \mathrm{a}$; for that posed by forgetfulness, see Rep. 486c-d; on the need for reminders, see Phdr. 276d, 277e-278a.

${ }^{48}$ Frede, "The Impossibility of Perfection," 745-46.

${ }^{49}$ Demos (Lyric Quotation, 28) seems to think that hyperbaton is precluded by the word order, but this seems to be too strong a position. 
In the last part of the parody $(346 \mathrm{c}-347 \mathrm{e})$, Socrates concludes, given the impossibility of being good, that a median state between good and bad must be regarded as acceptable and praiseworthy. There are several relevant lines:

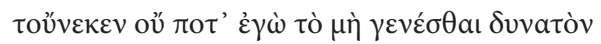

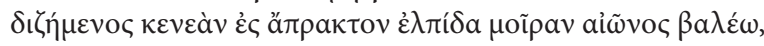

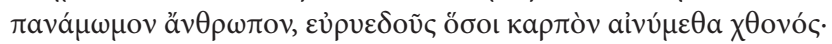

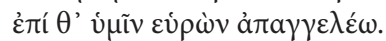

Therefore never shall I seek for the impossible

Cast away my life's lot on empty hope, a quixotic quest

For a blameless man among those who reap

The broad earth's fruit,

But if I find him, you will have my report. $(345 \mathrm{c} 6-\mathrm{II})^{50}$

$\cdots$

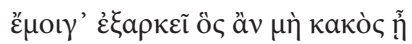

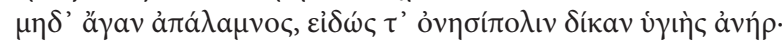

oú $\mu \mathrm{\varepsilon} \dot{\varepsilon} \gamma \dot{\omega} \mu \omega \mu \eta \dot{\sigma} \sigma o \mu \alpha \mathrm{L}-$

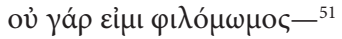

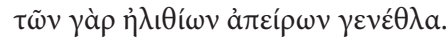

Enough for me a man who is not bad

Nor too intractable, who knows civic Justice, a sound man

I shall not blame him

For I am not fond of blame

Infinite the tribe of fools. $\left(346 c_{3}-8\right)$

$\cdots$

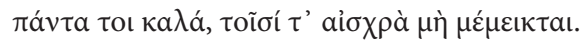

All is fair in which foul is not mixed. (346ci I)

The final line would seem to indicate that Simonides think that the mere absence of badness, or shamefulness, aỉoxpà, is sufficient for goodness. Indeed, this seems

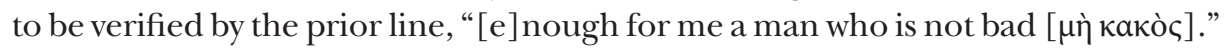
But Socrates dismisses this idea as "laughable in many ways" (346d2) and claims that Simonides instead means that a "sound man," or v́yıฺ̀ àví $\rho$, is one who is in a median state that is free from blame. ${ }^{52}$ When Simonides suggests that he will give his "report" if he happens to find $\pi \alpha v \alpha$ á $\omega \mu$ ov ä $v \theta \rho \omega \pi o v$, "a blameless man," Socrates takes him to mean that he will never praise anyone as fully good, but that he is "happy with a someone in the median state who does no evil" (346d 2-3).

${ }^{50}$ Toward the end, Socrates's interpretation loses a bit of focus. He mentions these lines, but he neglects them for over a Stephanus page, instead choosing to quote and interpret the lines relating to praise and unwillingly doing wrong.

${ }^{51}$ The text is indented thus because there has been no agreement on whether this line is actually part of the poem or Socrates's interpolation. For those who think that it is the latter, see e.g. Burnet, Platonis Opera; Taylor, Plato: Protagoras; Denyer, Plato: Protagoras; and Beresford, "Nobody's Perfect." Those who think that the line is part of the poem include, e.g. Lamb, Plato: Laches, Protagoras, Meno, Euthydemus; Bowra, Greek Lyric Poetry; and Croiset, Platon: Protagoras. Since nothing in my own argument hangs on this point, I take no stand here.

${ }^{52}$ It would not be far off to translate 'v́yı̀n' as "healthy" (see LSJ, s.v.), and, on a Socratic conception, the sound or healthy man has perhaps been treated by what Socrates earlier describes as "a physician of the soul" (3 $\mathrm{I} 3 \mathrm{e} 2)$. 
Both Frede and McCoy point to the Symposium as an analogue for what Socrates has in mind in talking of the median state,,$^{53}$ but it seems to me that the idea of human wisdom in the Apology would do just as well. There Socrates distinguishes among three states: divine wisdom, human wisdom, and human ignorance. The first is inaccessible, the second is a possible human achievement-Socrates's selfknowledge-and the last is the blameworthy state in which most Athenians live their lives $(22 \mathrm{e}-23 \mathrm{~b} ; 29 \mathrm{a}-\mathrm{b}) .{ }^{54}$ Further, in the Apology, Socrates associates this median state, his human wisdom, with never having willingly done evil (25e-26a; $33 \mathrm{a} ; 37 \mathrm{a}-\mathrm{b}$.). ${ }^{55}$ Thus construed, the median state is indeed praiseworthy, and, as Socrates's description of his quest in the Apology attests, the search for a man with divine wisdom is (as the poem puts it) "a quixotic quest," and the tribe of those ignorant of their own ignorance is infinite (2ra-22d).

Unless Socrates takes Simonides to mean something like the Socratic picture just sketched, it hardly makes any sense that he would dedicate an entire poem to the refutation and censure of Pittacus. The latter's claim is, after all, hardly evidence that he fails Simonides's median state test in its literal version. Only on the Socratic interpretation does Pittacus deserve to be refuted and rebuked. For in claiming that to be good is hard, Pittacus implies both that divine wisdom is possible and, by implication, that he possesses some of it. Thus, Socrates concludes by saying to Pittacus, with Simonides's voice, “[I]f you spoke something even moderately [ $\mu \varepsilon \dot{\sigma} \sigma \varsigma]$ reasonable and true, Pittacus, I would never censure you. But the fact is that you have lied blatantly yet with verisimilitude about extremely important matters, and for that I do censure you" (346e $4-347 \mathrm{a} 3) .{ }^{56}$ In censuring Pittacus in this way for failing to speak the truth, Simonides (on Socrates's interpretation) thereby endorses his own view as the true one. But since it is Socrates's view that Simonides is made to endorse, then it is Socrates's view whose truth is endorsed by Simonides. In this way, Socrates makes Simonides out to be a witness for his view of the human condition, that is, he employs the poet's authority as a way to endorse his own view.

${ }^{53}$ Frede, "The Impossibility of Perfection," 743-45; McCoy, "Socrates on Simonides," 357.

${ }^{54}$ The notion of the neither good nor bad in the Lysis might also be seen as describing a similar picture $(2 \mathrm{I} 6 \mathrm{c}-2 \mathrm{I} 8 \mathrm{c})$. In the context of trying to find a conceptual apparatus to account for friendship, Socrates claims, as an implication of the claim that the neither good nor bad is friend of the good because of the presence of some bad, that "those who are already wise no longer love wisdom, whether they are gods or men. Nor do those love it who are so ignorant that they are bad, for no bad and stupid man loves wisdom. There remain only those who have this bad thing, ignorance, but have not yet been made ignorant and stupid by it. They are conscious of not knowing what they don't know" $(2 \mathrm{I} 8 \mathrm{a}-\mathrm{b})$. This provides a picture of three levels: the wise gods, the philosophers, and the ignorant. Again, the median state is praiseworthy. Thus, pace Frede, one does not need the context and concepts of the Symp. in order to make sense of the Socratic picture presented in the Prt.

${ }^{55}$ As an anonymous reviewer rightly points out, this evidence is ambiguous, since on the Socratic picture, no one ever does evil willingly. For my modest purposes here, however, it is enough that Socrates associates the median state with not doing evil. To speculate as to how Socrates's claim differentiates him from his accusers in the $A p$., for example, is beyond the scope of this paper.

${ }^{56}$ Despite Socrates's use of vocatives, it is quite clear that these lines are not addressed to Pittacus. They are rather addressed, as the entire poem is, to Scopas, and, based on the principle that poets did not criticize their patrons, it seems safe to infer that, on the picture presented by Simonides, Scopas is praiseworthy. 
Socrates's methodology here is not, as Pappas would have it, a radical application of the principle of charity, whereby "[i]n order to derive true statements from a poem, Socrates is positively compelled to attribute his beliefs to every author." ${ }^{7}$ The clearest evidence for this is that the purported methodology contradicts both the content of the view that Simonides is made to endorse and the practice of philosophical dialogue in which Socrates engages. For Pappas's view entails that Socrates is so secure about the truth of his own views that he will impute them onto any poem whatsoever. But the content of the view about which Socrates is supposed to be so confident entails that no one should ever be that confident in the truth of one's own views. Thus, the philosophical content of Socrates's claims, which involves uncertainty about the truth of one's beliefs, does not square with the methodology that Pappas attributes to him, since this methodology would involve precisely such certainty. In fact, on Pappas's view, given his insistence that the treatment of the poem "strikingly resembles his treatment of live interlocutors, ${ }^{58}$ it would turn out that no real living dialogue is justified either, since everyone would be better off if Socrates just spoke for his interlocutors, saying on their behalf whatever he thinks is true.

In my view, Socrates's parasitic interpretation parodies some of the very same features that his parody of eristic interpretation did. First, Socrates's parody is an epideictic speech, showing that he is superior to the sophists both at giving speeches and at parasitic interpretation. Indeed, immediately following Socrates's interpretation, Hippias wants to give one, claiming that he "has quite a nice talk on it [himself]" which he is eager to present (347a6-b2). We are meant to imagine that Hippias's speech, though perhaps less obviously ludicrous, would be equally self-aggrandizing. Indeed, Hippias's enthusiasm and eagerness to present his own speech seems to be evidence for the sophistic practice of parasitic interpretation. Second, Socrates has a mercenary attitude toward the text. Socrates's interpretation does not hold itself to even any minimum standards of adequacy. Where the overt content points in one direction, Socrates understands the text to indicate something quite different. What we see in this parody is Socrates distorting the text to fit his own preconceived notions of virtue, goodness, and human success; in particular, he see in the poem various expressions of the basic claim that virtue is knowledge. Third, Socrates uses Simonides as a vehicle for the expression of his own ideas, that is, he makes it seems like Simonides is a philosopher who engages in refutation, thinks that virtue is knowledge, and endorses a Socratic picture of the human condition. Socrates does not really comment on the content of the view that he is articulating, except to say that the lines of the poem can be understood in the self-serving way that he unpacks them. Socrates's interpretation is parasitic on Simonides's fame, and the only role for the poet is to add gravitas and legitimacy to the Socratic view. Fourth, Socrates does not seem genuinely concerned with the truth of his own claims. He fails to test and evaluate them; instead, he articulates them in a long speech without comment. In short, there is no philosophical dialogue or dialectic. Socrates keeps his own ideas at a dis-

\footnotetext{
57Pappas, "Socrates' Charitable Treatment," 256.

${ }^{58}$ Pappas, "Socrates' Charitable Treatment," 254.
} 
tance, as it were, only engaging them qua meaning of Simonides's poem. Even if the picture is itself Socratic and meant (parodically) to persuade the group, it is arrived in a methodologically suspect way, and those who are convinced of it by Socrates's speech will also arrive at it in a methodologically suspect way. Surely it matters how one arrives at a philosophical position.

\section{$3 \cdot 3$ Philosophical Interpretation}

The point of the parody is to enact, as it were, certain criticisms of sophistic interpretation of poetry, and we are now in a position to formulate the parodic criticisms and to articulate the underlying ideal of interpretation. In my view, the parody puts forth three basic criticisms, and, in light of these three criticisms, we can formulate three criteria for the underlying ideal: First, sophistic interpretation either implicitly or explicitly appeals to the authority of the poet as a way either to win fame for oneself by showing oneself superior to an allegedly wise man (eristic) or to lend persuasive weight to a claim or set of claims (parasitic). That is, to approach a poem thinking that a poet is an authority figure is either to be interested only in self-aggrandizement-which is, on the Socratic picture, characteristic of pretension to wisdom and never justified ${ }^{59}$ - or to think that the poet's authority bears some weight in the establishment of a claim-which is simply false, both from a methodological perspective and from the fact that the poets do not in fact possess the relevant authoritative knowledge. ${ }^{60}$ Thus, the ideal of interpretation would require remaining indifferent to the poet qua authority. Second, sophistic interpretation distorts the text under discussion either to make it say something implausible or contradictory (eristic) or to make it say what the interpreter wants it to say for his own persuasive purposes (parasitic). In neither case does the interpreter approach the text of poem as even potentially possessing any independent content of philosophical significance. Contrary to this, the ideal of interpretation would involve a plausible reconstruction of the poem's intended meaning so that a philosophical view may be formulated. Third, sophistic interpretation merely elaborates the supposed contradiction (eristic) or meaning (parasitic) of the poem, without genuinely attempting to assess the truth of the content of the claims under discussion. By contrast, the ideal of interpretation would necessitate a critical assessment, that is, the interpreter would test and investigate the truth of the view as formulated.

To sum up, the ideal of interpretation would thus involve the satisfaction of three basic criteria. The interpreter would be required to:

\footnotetext{
${ }^{59}$ If one actually possessed wisdom, then self-praise or self-congratulation might be justified, since wisdom is the greatest good, but the wise person would presumably never want or need to exaggerate his or her abilities.

${ }^{60}$ Demos (Lyric Quotation, 36) notes that the poets do not come in for the sort of criticism they normally get from Plato. The core problem, she avers, is with the majority and their treatment of the poets as authorities. Even though it is left unstated, surely this attitude is mistaken because the poets are not authorities.
} 
[I] Remain indifferent to the poet qua authority;

[2] Attempt a plausible reconstruction of the poem's intended meaning so that a philosophical view is formulated; ${ }^{61}$

[3] Critically assess and test that view.

Notice the similarity between these three criteria and Socrates's own practice of philosophical conversation: Socrates is never impressed by his interlocutor's status as an authority figure, and he always questions his interlocutor, helps him formulate a philosophical position, and then subjects his view to a rigorous critique. ${ }^{62}$ As I have reconstructed the ideal of interpretation, it is clear that an interpretation thus has to be philosophical if it is to have any value, that is, it has to be an imitation of philosophical dialectic. Given that these criteria emerged through dissatisfaction with a particular interpretation, we might say that they reflect standards internal to interpretation itself. ${ }^{63}$ One might object here that the second [2] and third [3] criteria are clearly external to interpretation, but recall that it was Protagoras, not Socrates, who wanted to use the interpretation of poetry as a way of discussing the nature of virtue and who introduced logical consistency as a constraint on one's interpretation. Thus, even he, at least implicitly, is committed to there being a philosophical view contained in the poem (as per [2]) that can be critically examined (as per [3]). To this, one might add that parasitic interpretation assumes that an audience will uncritically take the poet's meaning to be true. These criteria are also philosophical in another way, insofar as they require certain discourse-enabling dispositions. In the Gorgias, Socrates describes the ideal interlocutor as possessing three virtues: "knowledge, good will, and frankness" (487a2-3). ${ }^{64}$ Leaving aside the first for a moment, we might say that the second criterion [2] requires the virtue of good will, since the interpreter has to be both willing to help elaborate

\footnotetext{
${ }^{6}$ One might object to this formulation on the grounds that it seems to leave open the possibility that one might read philosophical content into the poem, as opposed to discovering it in the poem. My thanks to an anonymous reviewer for bringing this objection to my attention. I have phrased the point in this way in order to leave open the possibility that there may be implicit philosophical content, though no overt philosophical content. Just as Socrates's interlocutors implicitly commit themselves to philosophical positions, so too might poems have implicit philosophical commitments, which may need to be teased out. That said, I do not deny that there may be poems that contain no philosophical content whatsoever. However, as I mean to suggest by my discussion of Archilochus in section 5 below, there may be fewer of these philosophically barren poems than one might have thought.

${ }^{62}$ Pappas ("Socrates' Charitable Treatment," 254) thinks that Socrates's actual method "strikingly resembles his treatment of live interlocutors," in that he asks questions of an unexpected sort and reaches conclusions that the interlocutor does not intend, while insisting that the conclusion is in fact what the interlocutor really thinks. McCoy ("Socrates on Simonides," 359) similarly claims that Socrates's interpretation engages in a "dialogue with the poet," on the grounds that Socrates tries to "build upon and respond to what Simonides thinks." As far as I can tell, Socrates never even broaches the question of what Simonides thinks. As I will argue in more detail below, philosophical interpretation will precisely have to do what Socrates does not do in his parody, namely, engage in a kind of dialogue with the poem.

${ }^{63}$ Finding philosophical standards implicitly internal to other practices is not an untypical Socratic maneuver. Consider, for example, the treatment of rhetoric in the Phdr.; see Trivigno, "Putting Unity in Its Place."

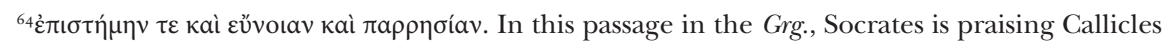
for possessing these three qualities, but it is clear from the context that this praise is ironic and from Callicles's behavior throughout the conversation that he actually lacks all three. See my discussion of this passage in Trivigno, "Paratragedy in Plato's Gorgias," 95-96, 95 n36.
} 
and open to countenancing another's view. The third [3] may be said to require the virtue of frankness, when the interpreter honestly and vigilantly pursues lines of criticism to test the adequacy of the view. Regarding the first virtue, knowledge, we can see that in play here as well, if we understand the knowledge criterion in the minimal, Socratic sense of knowledge of human ignorance. The interpreter could be said to embody knowledge of her own ignorance in [2], in her willingness to countenance the view of another, and knowledge of the ignorance of the poet in both [I] and [3], in being blind to the poet's authority and critical of his view. Understanding the knowledge criterion in this sense has the further upshot of dovetailing with the Socratic picture that the parodic interpretation actually endorses. In addition, satisfying these criteria will require skill in both constructive and critical argumentation and an overall orientation toward the truth, ensuring the telic structure of philosophical interpretation.

It is clear that philosophical interpretation, reflecting standards internal to interpretation itself, escapes the problem implicit in sophistic interpretation. However, it is not yet clear whether it is in general desirable to engage in such an interpretation, if one subjects interpretation to standards external to interpretation, in particular, to those of Socratic philosophical dialectic. We must see, in short, whether this model of interpretation can withstand the strong rebuke of interpretation that Socrates articulates after his parody is complete. If not, then the notion of a defensible kind of interpretation will be a non-starter. I turn to this task in the fifth section of the paper, after elaborating the critique in the next section.

\section{S OGRATES'S GRITIQUE OF I N T ERPRETATIO O $(347 \mathrm{C}-348 \mathrm{~A}$ )}

Socrates ends his interpretation of Simonides's poem with a stunning and sweeping rebuke of interpretation of poetry. In order to get clear on the main points of Socrates's attack, it is worth quoting the passage in full:

Discussing poetry [ second-rate drinking parties of the agora crowd. These people, largely uneducated and unable to entertain themselves over their wine by using their own voices to generate conversation, pay premium prices for flute-girls and rely on the extraneous voice of the reed flute as background music for their parties. But when well-educated men drink together, you will not see girls playing the flute or the lyre or dancing, but a group that knows how to get together without this childish nonsense, conversing civilly no matter how heavily they are drinking. ${ }^{65}$ Ours is such a group, if indeed it consists of men such as most of us claim to be, and it should require no extraneous voices, not

\footnotetext{
${ }^{65}$ Part of Frede's justification ("The Impossibility of Perfection," 747) for seeing Symp. as a crucial background text for understanding Prt. comes from the similarity of the description here to the actual events of the Symp. While there may very well be an inter-dialogue reference, Frede's assertion of a later hand lacks sufficient support. Frede ("The Impossibility of Perfection," 748) claims that the "references to the Symposium and the 'serious exegesis' $(343 \mathrm{c} 6-47 \mathrm{e})$ are later additions." Plato's purpose, in her view, was to provide a "caveat against reading the [Protagoras] in a too optimistic way," to assert the precarious state of human knowledge, and to use the account of the ascendance to truth from the Symp. in order to fill a gap in the Prt.'s treatment of education ("The Impossibility of Perfection," $749-50)$. Though her developmental thesis is weakly supported, Frede is surely right that, insofar as the interpretation passage provides information on the Socratic picture, it moderates the optimism one might find in the Prt. based only on the passages surrounding the hedonic calculus.
} 
even of poets, who cannot be questioned on what they say. When a poet is brought up in a discussion, almost everyone has a different opinion of what he means, and they wind up arguing about something they can never finally decide. The best people avoid such discussions and rely on their own voices to entertain themselves and to test each other. These people should be our models. We should put the poets aside and converse directly with each other, testing the truth and ourselves. $(347 \mathrm{c} 3-348 \mathrm{a} 6)$

The core of the passage is the ideal of "rely[ing] on [our] own voices," from which poetry distracts us. Socrates associates the introduction of "extraneous voices" with the uneducated hoi polloi, while the truly noble and educated "rely on their own voices to entertain themselves and to test each other." As I see it, Socrates makes three central and overlapping points in this passage.

The first point is that the poets "cannot be questioned on what they say." This is because they are present only through the words in their poems. The voice of the poet, though distinctive and original, cannot respond to questioning and testing and is thus in a certain sense inert. ${ }^{66}$ To have a proper voice, on Socrates's view, entails the ability to respond to philosophical questions. Thus, to replace one's own voice with the extraneous one of the poet is to take on a voice that does not speak properly. As Griswold puts this point, "In the standard game of exegesis ... neither the exegete nor the author whose works are explained can be questioned or refuted. Neither has his or her own voice or helps the other to find his or hers." ${ }^{7}$ In short, there can be no living dialogue. This point is reminiscent of the critique of writing in the Phaedrus, in which Socrates claims that writings cannot defend themselves without their authors or respond when questioned $(275 \mathrm{e})$. The voice of the poet will continue to say the same thing in a distinctively poetic and beautiful but philosophically unaccountable manner. One might add here that even if one could question the poets on their poetry, it is not clear that they would do any better than others at coming up with a coherent account, since as Socrates famously claims in the Apology, it was, in his experience, the poets themselves who were the worst at interpreting their own poetry $(22 \mathrm{~b}-\mathrm{c})$.

Second, because the poet's meaning can never be settled, there is no strictly correct interpretation and to argue about the proper interpretation of a poem is to engage in an inquiry that one "can never finally decide." ${ }^{68}$ The implications of this are wide-ranging, since "almost everyone has a different opinion of what [the poet] means." This does not seem to be merely a question of the difficulty of coming to the correct interpretation but rather of the impossibility that is endemic to interpretation as such. Since the poets themselves are not sure what they mean, interpretive claims about the poet's meaning lack proper truth-conditions. It is an open-ended endeavor with no clear termination point. One could spend one's entire life trying to determine the meaning of the works of Simonides and make no real progress. Since there are more important philosophical questions, pursuing interpretive ones would seem to be a waste of time.

The third point is explicitly normative: since "the best people . . rely on their own voices to entertain themselves and to test each other," and taking them as

\footnotetext{
${ }^{66}$ Griswold, "Relying on Your Own Voice," $29 \mathrm{I}-92$.

${ }^{67}$ Griswold, "Relying on Your Own Voice," 29 I.

${ }^{68}$ Cf. Hp. Mi. $365 \mathrm{c}-\mathrm{d}$.
} 
our "models," we "should . . . converse directly with each other, testing the truth and ourselves." I will dwell a bit longer on this point, both since it is the culmination of the other two and since it is not immediately obvious how to take it. Put briefly, living philosophical dialogue is the way to test the truth of our claims against others, and in doing so, to come closer to both knowledge of the topic and knowledge of self. Philosophical dialectic, as practiced by Socrates, thus has a necessary connection to knowledge and truth. ${ }^{69}$ Relying on the poet's voice distances oneself from the view under discussion and thus insulates one from criticism and responsibility to the outcome of the conversation. ${ }^{70}$ In this way, one is neither testing the truth nor oneself. Nor is one testing one's opponent; this is not inconsequential, since, as Griswold puts it, "to speak in one's own voice is closely linked to a receptiveness and responsiveness to the voice of others." ${ }^{71}$ In an obvious sense, the normativity here is methodological or epistemological, and, in a sense, conditional. If we want to emulate the best and get at the truth, then we should engage in philosophical dialogue. Of course, this implies that, if we are at the moment not interested in emulating the best, or are not really looking for the truth, then it seems perfectly fine to discuss poetry as a kind of harmless entertainment. However, Socrates appears to be making a much stronger point, that we should always emulate the best people, and that philosophical dialogue is the way to do so. Thus, the point he makes is more broadly ethical or moral. The "best" people are not merely the most successful seekers of knowledge because of certain methodological and epistemological views; they are the best because they are committed to the life of philosophical inquiry. Such commitment requires a single-minded-almost superhuman-devotion to philosophical conversation: notice that, on Socrates's account, we should be engaging in such conversation even when we are drinking at a party. The core underpinning of this view is the claim, central to the dialogue, that virtue is knowledge. Being a good person involves vigorously pursuing the truth and being open to Socratic testing, thus opening up the possibility of both knowledge and self-knowledge.

To sum up, interpreting poetry is deficient on several counts: by relying on the voice of the poet, we fail to test ourselves; by conducting a conversation with an interlocutor, the poet, who cannot respond, we cut off the possibility of real dialogue; and by conducting an argument about a matter, the correct interpretation of a poem, that is in principle undecidable, we cut off the possibility of truth. On Griswold's reading, these failures indicate an underlying moral ideal of discourse, which expresses the virtues of self-sufficiency, in testing claims for oneself; of accountability, in holding one's own claims to the standards of rational testing; and of responsibility, in responding appropriately when the claims under discussion are

\footnotetext{
${ }^{69}$ This is a large claim, which I will not defend here. At minimum, it should be uncontroversial to claim that Socrates thinks dialectic to be the methodologically preferable way of examining philosophical issues, and such methodological superiority is plausibly connected to success in differentiating true views from false ones.

${ }^{70}$ Griswold ("Relying on Your Own Voice," 289) claims that "Socrates tries to get Protagoras to say what he thinks in order to force him to acquire a stake in the continuation and outcome of philosophical dialogue."

${ }^{71}$ Griswold, "Relying on Your Own Voice," 290.
} 
upheld or refuted..$^{72}$ Since Socrates conceives of his recommendations as having normative ethical force, then to waste one's time interpreting poetry would be an ethical failure. If these criticisms are seriously meant—given that Socrates subjects interpretation to the standards of philosophical dialectic, there is no reason to doubt it - then it is hard to see how Socrates's own interpretation could be meant seriously. It must, rather, be doing critical work as a parody.

Bracketing philosophical interpretation for the moment, these criticisms can be seen as a direct challenge to Protagoras's model of education and his sophistic conception of the interpretation of poetry. Recall that, for the sophist, "the

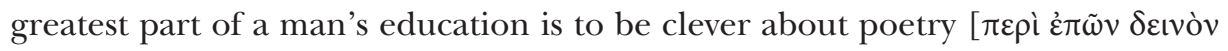
عival]" (338e6-339aI) and that this cleverness encompasses four tasks: (I) to understand what the poet means; (2) to understand what is composed correctly and what not; (3) to know how to analyze a poem; and (4) to know how to give an account in response to questions about the poem. If Socrates's critique is right, then (I) is impossible, (2) is to apply arbitrary and disingenuous standards, (3) amounts to the ability to distort the text to suit one's interpretive aim, and (4) is nothing more than a facility in eristic argumentation. ${ }^{73}$ One might ask to what end is cleverness about poetry aimed, or why, on the Protagorean model of education, it has such a prominent place. As we have seen, Protagoras's aim in his own interpretation was to bolster his own reputation. This is not incidental to, but rather a core component of, Protagoras's overall world-view. To establish an authoritative reputation through public display is part of what it means both to be virtuous and to hold a position of power in the city. In describing what he knows and what he teaches, Protagoras highlights the management of one's own affairs as well as those of the city (3 I8e-3 I9a). The Protagorean model involves building oneself up, in part through persuading others that one is virtuous. By contrast, the Socratic model involves constantly breaking oneself down through dialectical testing, examination, and inquiry-in short, through philosophy. It is to confront one's own ignorance again and again. Protagoras only wants to win and will only engage in verbal disputes in which he already has the advantage; in refusing to accede to Socrates's request to give only short answers, he says, "I have had many

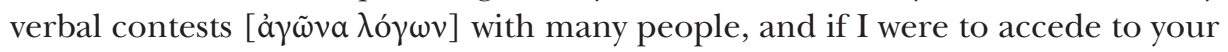
request and do as my opponent demanded, I would not be thought superior to anyone, nor would Protagoras be a name to be reckoned with among the Greeks" $(335 \mathrm{a} 4-8)$. To put it bluntly, Protagoras is not interested in genuinely testing himself, since, on his picture of virtue, nothing good can come of it.

When Protagoras says that he wants to question Socrates about virtue "transferred to the context of poetry" (339a4-6), this reveals another deep disagreement between Protagoras and Socrates on the nature of virtue and education. For Protagoras, there is no real difference between discussing virtue through dialectic

${ }^{72}$ Griswold, "Relying on Your Own Voice," 292.

${ }^{73}$ I mean the reference to eristic argumentation in (4) to encompass both eristic and parasitic interpretation. I conceive of eristic argumentation, more broadly, as argumentation that is directed at defeating one's opponent and has no concern for truth. One can engage in such argumentation whether one is criticizing the poets (eristic interpretation) or relying on their authority (parasitic interpretation). I thank an anonymous reviewer for pointing out the ambiguity. 
or in the context of poetry, since the ability to impress others by talking about virtue can be achieved through myth, argument, and the interpretation of poetry. Consider his own indifference to whether he answers Socrates's initial question about the teachability of virtue in an argument or a myth (320c3-7). For Protagoras, there is no preferred methodological approach because getting at the truth is simply not the point; to be capable in a plurality of forms of expression only increases one's persuasive possibilities. Thus, once Protagoras transfers the topic of virtue to the context of poetry, he changes the entire focus of the conversation. Something quite significant is lost in the transfer, namely, the relationship of the conversation to the topic of virtue, and with it, his own relationship to truth and self-knowledge. For both Protagoras and Socrates, being virtuous seems to involve being able to talk about virtue, but, for Socrates, the value of such a discussion consists in its orientation toward the truth.

Since Protagoras's conception of being $\delta \varepsilon \imath$ ó the virtues implicit in philosophical dialectic, it is, as Socrates playfully suggested earlier in the dialogue, bad. It is to concede one's voice and to fail to exhibit philosophical virtue. And Protagoras himself is bad, insofar as he both fails to use his own voice and, in encouraging others to passively accept his wisdom, discourages others from using theirs. We see Protagoras's failure to use his own voice again and again in his continual refusal to participate in good faith in the philosophical conversation, as Socrates conceives of it. In other words, Protagoras will not use his voice to engage in dialectical conversation, will not test himself, is not responsive to the voice of others, and does not seem interested in the question of truth. He will only use his voice to lecture to others, to persuade them, and to attain a great reputation. Despite his enchanting voice and commanding presence (see 3 I 4e-3 I 5b), in Socrates's sense, he has no voice at all.

It is clear that these explicit criticisms target at least sophistic interpretation. It was Protagoras who introduced the notion of interpretation as a methodology in the first place, and his sophistic version of it seems to be at stake throughout. In addition, Socrates is talking primarily to a group of sophists, whose shared assumptions about interpretation seem a relevant constraint. Further, Socrates does not mark any difference between his own parody of sophistic interpretation and the kind of interpretation he criticizes. Indeed, the content of the three parodic criticisms anticipate and partly correspond to the criticisms of interpretation that Socrates explicitly articulates. ${ }^{74}$ Both sets of criticisms share and respond to worries about the role of the absent poet,,$^{75}$ the possibility of settling the question of the poem's meaning, and the way that the focus on poet and poem distracts us from the pursuit of truth. However, there are also reasons to think that the target

${ }^{74} \mathrm{As}$ I argue, in both $M x$. and Crat., Plato employs both explicit argument and parodic distortion in order to criticize a non-philosophical methodology or practice: see Trivigno, "The Rhetoric of Parody," and "Etymology and the Power of Names."

${ }^{75}$ Pappas ("Socrates' Charitable Treatment," 255), McCoy ("Socrates on Simonides," 359), and Frede ("The Impossibility of Perfection," 747) all claim that Socrates, in his interpretation, uses his own voice. I admit that there is a sense in which he does, but it is decidedly not the sense that is relevant to Socrates's critique of interpretation here. A core part of using one's own voice involves testing the truth and oneself. Socrates does neither of these in his interpretation. 
of explicit critique might be more general than merely sophistic interpretation. Sophistic interpretation operates within and takes its bearings from a larger cultural context in which facility with the interpretation of poetry plays a prominent role. ${ }^{76}$ Thus, the general criticisms may be said to be aimed at the contemporary practice of interpretation, of which sophistic interpretation is an advanced version. Indeed, Socrates's focus on what happens when poets are interpreted in a discussion would seem to confirm this point, suggesting that such discussions were not infrequent.

A further question concerns whether the criticisms target the model of philosophical interpretation as well. While the notion of philosophical interpretation was implied by standards internal to interpretation itself, Socrates here seems to be employing the standards of philosophical dialectic to critique interpretation in general. From the perspective of the former standards, the point seems to be that we should interpret poetry in a philosophical way; from that of the latter, the point seems to be that we should do philosophy and not interpret poetry at all. In the next section, I show how these two positions are ultimately compatible.

\section{VALUE AND TRUTH IN INTERPRETATION?}

In this section, I am, to a certain degree, leaving the text behind and trying to think through the implications of explicit criticisms examined in section 4 in relation to the ideal formulated at the end of section 3. In short, I attempt to see whether and under what conditions the ideal can escape the criticisms. To repeat, the ideal of interpretation-philosophical interpretation-would involve satisfying at least three basic criteria:

[I] Remain indifferent to the poet qua authority;

[2] Attempt a plausible reconstruction of the poem's intended meaning so that a philosophical view is formulated;

[3] Critically assess and test that view.

Given the criticisms outlined in section 4, philosophical interpreters should be using their own voice, that is, testing themselves and aiming at the truth.

The first criterion of genuine interpretation is explicitly psychological. A philosophical interpreter must have and display a certain attitude of indifference toward the reputation and alleged wisdom of the poet; in short, he is not to be treated as an authority figure. This attitude can enable the interpreter to test herself and aim at the truth, since she will be neither insulated from responsibility to the view, since it is the poet's view, nor distracted by the poet's status when it comes to the assessing the philosophical content of the view. In this way, an interpreter can avoid relying on the voice of the poet, while at the same time making use of the poet's words. A sophistic interpreter approaches a poem as the words of a potential ally or rival in the pursuit of reputation and standing in the community. Thus, he cannot help but see the poet as an authority figure and thus his interpretations-eristic or parasitic - will rely on the voice of the poet to the epistemic gain of neither. The philosopher, by contrast, will not presume that the poet is wise. She will thus be tempted neither to try to show herself wiser by criticizing the poet

${ }^{76}$ Halliwell, "The Subjection of Muthos to Logos," 94-98. 
nor to show herself wise by knowing what the poet knows. At worst, the poet will seem no better than the sophist in that he is engaged in the pursuit of fame and honor. At best, the philosopher will see in the poet someone who is attempting to express a true claim. Either way, the indifference to the poet qua authority figure means that the philosopher should adopt a critical attitude when approaching the work of the poet. This attitude should not be purely disparaging, as eristic interpretation is in the pursuit of fame, but intelligently critical, as the elenchus is in the pursuit of knowledge.

The second criterion shifts the focus of attention from the poet to the poem. ${ }^{77}$ As we have seen, the sophistic approach to the poem is mercenary. The philosophical approach can be said to be mercenary in a certain sense as well. For a philosophical interpreter will make the poem suitable for discussion by attempting a plausible reconstruction of the poem's intended meaning in such a way that a philosophical view, that is, a position with truth-conditions, emerges. In this way, one's interpretation can aim at the truth. This blunts the force of the criticism that the meaning of a poem is never fully decidable, without entirely giving up the idea that the author's meaning should play some role in constraining interpretations. If responsibly using one's own voice entails a kind of receptivity to the voice of others, then a philosophical interpreter will exhibit the virtue of good will, in her willingness to formulate a view out of the poem and her openness to countenancing it, even if it is strange or radically different from her own. Many of Socrates's interlocutors fail to exhibit the virtue of good will in refusing even to countenance claims that Socrates makes-for example, it is better to be wronged than to wrong-since they are so alien and unexpected. In order to use a poem to test oneself, one needs to be open to the possibility that there is something in the poem that one can learn from. This does not mean that one should expect to be a passive learner. On the contrary, the reconstruction of the poem's meaning will require thinking beyond what is explicitly stated in the text to, for example, underlying premises. ${ }^{78}$ It may require, as the example of Simonides's poem and its relation to Pittacus suggests, that one reflect on the larger intellectual context in which the poem was composed. Poets are often responding to one another and to events and attitudes in their cultural-historical context; thus, understanding what poets say may require understanding this more or less implicit context. By engaging the poem in this complex quasi-dialogue of discovery, one can partially overcome the problem that the poet cannot be questioned. One can question poets in absentia by thinking through the view for them.

The third criterion of philosophical interpretation is that one ought to critically assess and test the view expressed. If done properly, both the interpreter and the

${ }^{77}$ Pappas ("Socrates' Charitable Treatment," 257-58) rightly see that the focus on the author is potentially distracting from the question of truth.

${ }^{78}$ However, the poem is, at least in part, supplanted as the proper locus of unity, since it is the view that begins to take center stage at this point. Along these lines, Halliwell ("The Subjection of Muthos to Logos," IIO-I2) argues that Plato's reading of poets is anti-contexualist, in the sense that he does not make an effort to place claims within the context of a larger work and does not seem interested in drawing distinctions between the poet and his characters. This is what allows Socrates to quote short lines of poetry out of context in the course of a discussion. However, Halliwell does think that Plato thinks of the larger ethical, cultural, and intellectual milieu when citing poetry. 
truth of the claims can be tested. The absent poet would obviously not get any of the benefits of the critical examination. Socrates's parody, recall, failed precisely in this regard: it did not test or critique the view at all. But a rational assessment would seem essential to the maintenance of an appropriately critical distance. In discovering and/or reconstructing a philosophical view from a poem, one has set the stage for the critical evaluation, which on this view is the culmination and most important aspect of interpretation. It is not enough simply to reconstruct the view. If satisfying [2] requires the virtue of good will and a kind of dialogue of discovery, then satisfying [3] requires the virtue of frankness and a kind of elenchic dialogue. Through questioning the view and vigilantly pursuing lines of criticism, one can test the adequacy of the view. Whereas the first two criteria explicitly or implicitly left the poet behind, the third leaves the poem behind. Once the view is formulated, its connection to the poem (and thus to the poet) becomes irrelevant, and the philosophical view takes center stage. In short, criterion [3] requires philosophy. In this way, the interpretation of poetry transcends itself, and interpretation becomes an essentially philosophical endeavor.

We are now in a position to say more precisely in what way the ideal of interpretation, according to which one should interpret poetry in a philosophical way, can withstand Socrates's explicit criticisms of interpretation, which seemed to suggest that one engage in philosophical dialectic and not interpret poetry at all. Since philosophical interpretation transcends itself and moves from the interpretation of poetry (narrowly construed) to philosophical dialectic, it constitutes both a new way of interpreting poetry and a way of leaving the interpretation of poetry behind. To the extent that the activity of interpretation has any value, it will have such value only insofar as it puts the interpreter, who brings the poem into the space of reasons, into a possible relationship to the truth. In sum, the interpretation of poetry only has value to the extent that it imitates living philosophical dialogue in its engagement with the poem and provokes philosophical reflections aimed at the truth. This value is limited and parasitic on philosophical dialectic, which gets its value from its relationship to truth.

As I have reconstructed it, the ideal of interpretation does alleviate the force of the explicit criticisms, and it seems possible both to interpret a poem while at the same time using one's own voice and aiming at the truth. However, there are some residual difficulties, which threaten to make the practice of philosophical interpretation quite difficult to achieve successfully. Success is contingent on one's ability to navigate a tension at the heart of philosophical interpretation between criteria [2] and [3], which pull us, as it were, in different directions. If one is caught up exclusively with the task of trying to elaborate the poem's meaning, then one is focusing on the wrong activity. The formulation of a philosophical view is instrumental to the critical evaluation, and an interpreter ought not aim primarily at the plausible reconstruction, but at the potential truth of the philosophical claims under discussion. An interpreter constructing a philosophical interpretation will display his proper epistemic attitude by being oriented primarily by and toward the truth of the claims at stake. In other words, there is a hierarchy of concern, in which interpretive fidelity is trumped by the truth. This hierarchy need not involve or imply a breach of the virtue of good will. That is, this does not imply 
that an interpreter employ Pappas's version of the principle of charity, whereby she attributes to a poem only true claims, or claims she already thinks are true. In fact, employing the principle of charity thus construed would not only represent a failure to meet criterion [2], since one is not open to a different view, but it would also represent a failure to meet criterion [3], since one does not in any relevant sense critically assess and test the view under discussion. The tasks involved in satisfying [3] thus depend on those involved in satisfying [2], but it is not clear when we have adequately satisfied [2]. In short, it is not quite clear at what point the task of elaboration is over, and there are no direct adequacy conditions for the satisfaction of [2]. We must guard against the possibility of expending too much effort on exposition, but we must also guard against expending too little and moving to critical analysis too quickly. ${ }^{79}$ There seems to be no straightforward way of eliminating the tension.

The persistence of this tension suggests that the dialogue of discovery with the text-governed by the virtues of good will—and the elenchic dialogue-governed by the virtues of frankness-are perhaps not neatly separable into distinct tasks. Or alternatively, they may be theoretically or ideally separable, but this separation may prove in practice extremely difficult. It may be instructive to look briefly at Plato's own practice of critical interpretation-albeit of a philosophical work-in the Theaetetus. Shortly after Socrates declares that the exposition of Protagoras's epistemology is completed (I6od-I6Ib) and begins to critically evaluate it, he stops, complains that he and his companions are "crowing" before victory is won ( $164 \mathrm{C} 5-6$ ), and, invoking the "interests of justice" (I64e7), ${ }^{\circ \circ}$ he goes back to the task of exposition in order to "rescue" Protagoras (I65a6-7). Indeed, Socrates complains that they have adopted the methods of controversialists, using a (merely) seeming contradiction to refute a view $(\mathrm{I} 64 \mathrm{c} 8-\mathrm{d} 2)$. This suggests that their elaboration of the view had not been fair because it had been implicitly tainted by the critical evaluation; what Socrates does, then, is reformulate parts of the Protagorean position such that it becomes both a more accurate and coherent reflection of Protagoras and a more difficult position to refute. Thus, we might think of the hierarchy of concern as involving a kind of reflective equilibrium between the virtues of good will and frankness, which will help us think and ideally move us toward the truth. But the need for such a reflective balancing act suggests that we cannot simply and easily separate our reconstruction of a view from our critical assessment of it. At what point the demands of good will and justice in exposition end may not be clear to us until after we have begun to criticize.

${ }^{79} \mathrm{~A}$ version of this problem comes in recent debates about the history, or historiography, of philosophy. What Daniel Garber ("What's Philosophical") calls the "antiquarian approach" to the history of philosophy involves placing an author's view in the context of the author's body of work, his intellectual context, and his larger social and historical context. In Garber's brief exposition of the antiquarian's version of Descartes, he asks, at increasingly broad levels of context, "But why stop here?", suggesting that the task of the antiquarian historian of philosophy is interminable (I32-37).

${ }^{80}$ Socrates invokes justice on the grounds that "they are trampling an orphan" ( $\left.164 \mathrm{e}_{3}-4\right)$, since Protagoras is not merely absent but dead; cf. Phdr. $275 \mathrm{~d}-\mathrm{e}$, where a written text is described as an orphan, which "when attacked unfairly, always needs its father's support." Though I will not pursue the point here, it may be that conversational and interpretive good will are both functions of justice. 
A further worry with respect to [2] concerns the suitability of certain poets and poems for philosophical extrapolation and examination; it is plausible to suppose that some will require more exertion on [2] and others less. One might even be inclined to think that some poets and their poetry are simply unsuitable for philosophical interpretation, but given Socrates's ability to see philosophical commitments in even the most innocuous-seeming comments, ${ }^{8 \mathrm{I}}$ we should be careful about embracing this position. Consider, for example, the case of the warrior-poet Archilochus, whose poetry, which ranges from the intensely vindictive to the military-political to the nearly pornographic, might seem prima facie unsuitable for the kind of analysis suggested here. In one of his more famous poems (West 5), he writes,

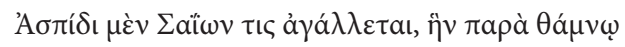

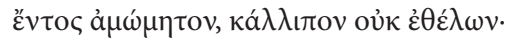

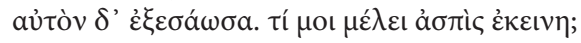

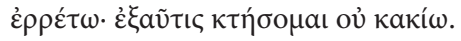

Some Thracian delights in my shield, which near a bush

I left unwillingly, a blameless armament.

Myself I saved! Why should I care about the shield?

To hell with it! I'll get another one, just as good. ${ }^{82}$

One might be tempted to pass this poem over on the grounds that it is personal, narrative, and about a shield. But it is clearly not merely that, for abandoning one's shield was seen as the paradigmatic act of cowardice, and Archilochus, writing during the archaic period, can and has been seen here as challenging the older epic tradition and its ideals of bravery and manhood. ${ }^{83}$ Such ideals were still in fashion even in the classical period. After quoting the first three lines of the poem, Sextus Empiricus reports the story of the Spartan mother who told her son before going off to battle to return either with his shield or on it, that is, dead. ${ }^{84}$ Archilochus's decision, as depicted here, represents an evaluation of the relative importance of one's life and one's reputation and, in criticizing the Homeric-epic and contemporary cultural ideals of courage, might be said to implicitly endorse an alternative conception of virtue. In rejecting "death before dishonor," he seems to be celebrating his own craftiness in escaping death.

In developing a philosophical position out of this poem, we might take as our starting point something like the claim that death is an evil. From there, we could extrapolate that life is a good and begin to tell a story about virtue or excellence as concerning the preservation of one's life. This sketch has moved altogether too quickly, but notice that we are already on philosophical ground and an analysis of the philosophical content of the poem is now possible. Indeed, it is highly likely that a critical evaluation of an extrapolated version of this content from the Socratic

\footnotetext{
${ }^{8}$ For example, Socrates manages to draw a philosophical view out of Ion's boasting (Ion 530a-53Id), Euthyphro's intention to prosecute his father (Euthphr. 3e-4e), and Cephalus's claim that wealth keeps one from having to cheat or deceive (Rep. $33 \mathrm{Ia}-\mathrm{d}$ )

${ }^{82}$ The Greek text is from West, Iambi et Elegi Graeci: Ante Alexandrum Cantati; the translation is my own.

${ }^{8}$ See Burnet, Three Archaic Poets: Archilochus, Alcaeus, Sappho, 4I-42, for an analysis of the way that poem "strips this shield of its symbolic power, reducing it to a mere object that can be bought and sold."

${ }^{8}$ Pyrrh. Hyp. 3.216.
} 
perspective will reveal severe shortcomings. A typical Socratic countermove would be to suggest that it is not merely life, but a good life, that has value. Notice here that even from a presumably false view of the human good one could manage to move toward truth. One might see this as parallel to the way that the elenchus begins with a claim, investigates it to find underlying premises and assumptions, crafts a philosophical view, critiques that view, and comes to reject it as false even while making progress toward understanding the topic at hand (where progress can be understood even in the minimal sense of the clearing away of a false view). ${ }^{85}$ Further, if philosophical dialogue is valuable not merely as a means to the demonstration of true propositions ${ }^{86}$ but as the lifelong activity that is constitutive of the good life for a human being, then interpretation, insofar as it is philosophical, has value as a component of this life.

\section{OBJEGTION: POETRY A S ARMFUL DIVERSION}

I have suggested that the philosophical model of interpretation can partly escape the critique of interpretation that Socrates offers, insofar as philosophical interpretation transcends itself. Regardless, one might be inclined to object that the interpretation of poetry is not necessary to the attainment of truth, and, since there is no good reason to take the poets seriously as authorities, ${ }^{87}$ it is likely to be a harmful diversion as well. In short, there needs to be some truth to be had through the interpretation of a poem, and if there is not, then while philosophical interpretation of poetry is possible, there really is no point. Why should anyone bother with poetry at all? It is, after all, an extraneous voice, and Socrates says, "[O] urs is such a [well-educated] group, if indeed it consists of men such as most of us claim to be, and it should require no extraneous voices, not even of poets" $(347 \mathrm{e} I-3)$. It may be conceded that "the best," on Socrates's account, at least when they are at their best, will not bother with poetry. The best are surely the wise ones, whose possession of knowledge renders the voices of others superfluous, but it is far from clear that Socrates considers the sophists or himself to be part of this "divine" group-note the conditional nature of the claim. Indeed, if Socrates's interpretation does provide information on the Socratic view, then, since perfection is unattainable, no human being will satisfy this criterion. If the

\footnotetext{
${ }^{8}$ This analogy to the elenchus is not unproblematic, and I do not wish to engage here in a larger debate about the elenchus, its goals, and logical structure. In the case of poetry, since there is no real interlocutor at stake, the goal of interrogating a poem cannot be merely to prove the inconsistency of the poet's beliefs.

${ }^{86}$ Throughout my discussion of the interpretation of poetry, I have focused on the formulation and critical assessment of views, claims, and propositions, thus seemingly committing Plato to a notion of truth as concerned exclusively with the correctness of propositions. What, one might ask, of the notion of truth as the eidetic vision of the soul, as formulated in e.g. the Rep. and the Phdr.? This question goes beyond the scope of both this paper and the Prt. to address fully. In relation to the argument of this article, I will only point out that philosophical dialectic must itself be undertaken with propositions, and insofar as I have made dialectic the model for philosophical interpretation, it too will be concerned with truth-claims. Whether and how those propositions relate to and/or generate an eidetic vision is a matter for a larger project, though nothing in my exposition is intended necessarily to rule out a relationship between truth-claims and eidetic vision. I thank an anonymous reviewer for drawing my attention to this deep and important issue.

${ }^{87}$ Though this point is not made explicitly in this dialogue, it is very well-attested in others, most prominently in Ap., Ion, and Rep.
} 
best leave poetry entirely behind, then Plato himself would not qualify as one of the best, for, according to Halliwell, Plato's "engagement with poetry is so evident, so persistent, and so intense as to constitute a major thread running through the entire fabric of his writing and thinking." ${ }^{88}$ For the second best, however, interpreting poetry may be a valuable instrument in three ways: by provoking true intuitions, by providing a starting point for one's own philosophical reflections, and by enabling philosophical conversation with others. These considerations do not eliminate, but rather mitigate, the objection, for it may very well be that interpretation of poetry is a harmful diversion even for those who enter into it with philosophical intentions. For philosophical intentions are presumably not sufficient for navigating the tension between criteria [2] and [3], and one may, despite one's intentions, become mired in the task of elaboration.

First, interpreting a poem might reveal something true. Even though it would be a mistake to think of the poets as authorities, Plato elsewhere allows that some poetry contains truth. However, the source of the truth in poetry is attributed not to the poet but to the god. ${ }^{89}$ One might say that a divine thought-a kernel of truth-could be contained in a poem. In Simonides's poem, that thought may have been the one that makes divine goodness unattainable for man. We can think of this as a pregnant thought - to adapt a metaphor from the Theaetetus-and we may imagine Socrates, in thinking about Simonides's poem, testing that thought in his own internal reflections about the nature of goodness, virtue, and knowledge. Thus, the fact that Simonides himself does not mean what he says in the way that Socrates would find philosophically acceptable is irrelevant. In a quasi-dialogue with the ideas in the poem, Socrates might have managed to reconstruct a Simonidean position, to subject it to philosophical scrutiny, and to reject its overall meaning, while at the same time preserving a core insight of the poem. Only in such an interpretation could Socrates be said to be subjecting mythos to logos and using his own voice.

Second, a poem might provide a starting point for one's own philosophical reflections, and this may be useful whether or not the poem itself contains any divinely inspired truth. As Socrates practices it, dialectic needs an opinion to constitute the starting point for philosophical reflection, and he typically uses his interlocutors to provide that starting point..$^{90}$ In the absence of an interlocutor, a poem might provide a serviceable substitute. A philosopher, in testing the claims in a poem, engages in a kind of dialogue with it. The fact that Socrates claims to have actually paid attention to the poem ought to be a relevant consideration. One could think about the poem, engaging it in a silent dialogue, and this imita-

\footnotetext{
${ }^{88}$ Halliwell, "The Subjection of Muthos to Logos," 94.

${ }^{89}$ While it is certainly true that not all poems will contain divine thoughts, some poems may very well do so. Socrates claims, in Ap. 22a-d; Ion $533 \mathrm{~d}-535$ a, that the ultimate responsibility for a poem's truth and beauty lies with the gods. On the role(s) of divine inspiration, see Tigerstedt, Plato's Idea of Poetical Inspiration; Partee, "Inspiration in the Aesthetics of Plato"; and Trivigno, "Technê, Inspiration and Comedy." For a more skeptical view of inspiration, see Woodruff, "What Could Go Wrong with Inspiration? Why Plato's Poets Fail."

${ }^{9}$ The literature on the elenchus is varied and vast, but the claim that it begins with the opinion of Socrates's interlocutor seems to be relatively uncontroversial. For a classic exposition, see Vlastos, "The Socratic Elenchus." On Aristotle's account of philosophical dialectic, it requires the analysis of endoxa, or received opinions; see e.g. Top. Iooa29-30.
} 
tion of living dialogue in thought—-though inferior to live dialectic-would be valuable nonetheless.

Last, interpreting poetry might have the indirect advantage of further enabling a philosopher to engage in dialectical discussion with others. ${ }^{91}$ The poets were taken very seriously as sources for wisdom by $5^{\text {th }}$ and $4^{\text {th }}$ century Greeks. In such a historical context, it seems all the more imperative for a philosopher to take poetry seriously, to challenge and test poems in the search for understanding to see whether or not they contain any truth. Thus, familiarity with poetry might prove useful in conversations, in which poets were common points of reference. Plato portrays Socrates as having extensive knowledge of poetry, and this knowledge almost always comes up in a dialectical context.

\section{G O N C L U S I O N}

In this paper, I hope to have shown that the puzzle I began with can be resolved if we understand Socrates's interpretation of Simonides's poem to be a parody, which articulates implicit criticisms of sophistic interpretation that overlap with and partly anticipate the explicit criticisms Socrates voices. The parody reveals that sophistic interpretation-both eristic and parasitic-appeals to the authority of the poet, employs an exploitative and mercenary attitude to the text of the poem, and exhibits an indifference to the truth of the claims under discussion. The parodic criticisms rely on an ideal of interpretation, philosophical interpretation, whereby an interpreter remains indifferent to the authority of the poet, attempts a plausible reconstruction of the poem so that a philosophical view is being articulated, and critically assesses and tests this view. Such philosophical interpretations have a hierarchy of concern, which subordinates textual fidelity to the pursuit of truth. This model of interpretation is compatible with using one's own voice, that is, testing oneself and aiming at the truth; in other words, it can partly escape the explicit criticisms Socrates voices against interpretation. Sophistic interpretation of poetry has no value, while philosophical interpretation has limited value, due to its possible relation to truth. I want to end by suggesting that this account of the interpretation of poetry may have broader significance for a more general hermeneutics, since it is not obvious that the poetical form of the object of interpretation makes any significant difference to the account of interpretation articulated here. In particular, the account might apply mutatis mutandis to the interpretation of works of philosophy ${ }^{92}$ as well and thus might be

${ }^{91}$ Aristotle (Met. 995a7-8) claims that certain people will only take a view seriously if a poet can be cited as an authority for it. Thus, familiarity with poets might be useful for the philosopher trying to engage people in dialectic. Even Aristotle himself, though dismissive of the idea that philosophical ideas need support from poetry, cites poetry extensively; see Moraitou, Die Äusserungen des Aristoteles über Dichter und Dichtung ausserhalb der Poetik.

${ }^{92}$ There are, in addition, some good historical reasons for supposing the account to apply equally well to philosophical works, especially since some major pre-Socratic philosophers, Parmenides and Empedocles, composed their books in verse. Anaximander's terms for the originating substance are described by Simplicius as “poetical” (in Phys. 24, I3). Further, understanding the meaning of Zeno's book of puzzles, or of Heraclitus's notoriously cryptic sayings could certainly qualify as an interpretive inquiry that one "can never finally decide." The Sokratikoi logoi, including the Platonic dialogues, were considered by Aristotle to be a species of mimetic poetry broadly construed (Poet. I447b9-II). 
used to formulate the conditions for philosophical interpretation of philosophy. ${ }^{93}$ If this suggestion is right, then the interpretation of philosophical works, like that of poetical ones, ought to aim to transcend itself by provoking living philosophical dialogue aimed at the truth. We can further imagine that Plato himself would both want and aim to be interpreted in just this way. ${ }^{94}$

\section{B I B L I O G R A P H Y A D A B B R E V I A T I O N S}

Babut, Daniel. "Simonide Moraliste." Revue des Études Grecques 88 (I975): 20-62.

Barney, Rachel. "Socrates Agonistes: The Case of the Cratylus Etymologies." Oxford Studies in Ancient Philosophy I6 (I998): 63-98.

Beresford, Adam. "Nobody's Perfect: A New Text and Interpretation of Simonides PMG 542." Classical Philology I03 (2008): 237-56. ["Nobody's Perfect"]

Bowra, C. Maurice. Greek Lyric Poetry. Oxford: Clarendon Press, 1936.

—. "Simonides and Scopas." Classical Philology 29 (1934): 230-39.

Burnet, John, ed. Platonis Opera, vol. III. Oxford: Clarendon Press, I977.

Burnet, Anne Pippen. Three Archaic Poets: Archilochus, Alcaeus, Sappho. London: Duckworth, 1983.

Cooper, John M., ed. Plato: Complete Works. Indianapolis: Hackett, 1997.

Croiset, Alfred, ed. and trans. Platon: Protagoras. Paris: Les Belles Lettres, I955.

Davidson, Donald. "Radical Interpretation." Dialectica 27 (I973): 3I4-28.

Demos, Marian. Lyric Quotation in Plato. Lanham: Rowman and Littlefield, I999. [Lyric Quotation]

Denniston, John D. The Greek Particles. Oxford: Clarendon Press, I934.

Denyer, Nicholas, ed. Plato: Protagoras. Cambridge: Cambridge University Press, 2008.

Dickie, Matthew. "The Argument and Form of Simonides 542 PMG." Harvard Studies in Classical Philology 82 (I978): 2I-33.

Donlan, Walter. "Simonides Fr. 4d and P. Oxy. 2432." Transactions and Proceedings of the American Philological Association Io0 (I969): 7 I-95.

Dorter, Kenneth. "The Ion: Plato's Characterization of Art." The Journal of Aesthetics and Art Criticism 32 (1973): 65-78.

Frede, Dorothea. "The Impossibility of Perfection: Socrates' Criticism of Simonides' Poem in the Protagoras." The Review of Metaphysics 39 (I986): 729-53. ["The Impossibility of Perfection"]

Garber, Daniel. "What's Philosophical about the History of Philosophy?" In Sorrell and Rogers, Analytic Philosophy and History of Philosophy, I29-46. ["What's Philosophical?"]

Garrett, Don. "Philosophy and History in the History of Modern Philosophy." In The Future for Philosophy, edited by Brian Leiter, 44-73. Oxford: Oxford University Press: 2006.

Griswold, Charles. "Relying on Your Own Voice: An Unsettled Rivalry of Moral Ideals in Plato's Protagoras." The Review of Metaphysics 53 (I999): 283-307. ["Relying on Your Own Voice"]

Halliwell, Stephen. "The Subjection of Muthos to Logos: Plato's Citation of the Poets." Classical Quarterly 50 (2000): 94-II 2. ["The Subjection of Muthos to Logos"]

Hatfield, Gary. "The History of Philosophy as Philosophy." In Sorrell and Rogers, Analytic Philosophy and History of Philosophy, 83-I 28.

Kenny, Anthony. "The Philosopher's History and the History of Philosophy." In Sorrell and Rogers, Analytic Philosophy and History of Philosophy, I3-24.

Lamb, William R., ed. and trans. Plato: Laches, Protagoras, Meno, Euthydemus. Cambridge, MA: Loeb Classical Library, I924.

Liddell, Henry G., Robert Scott, and Henry S. Jones, eds. A Greek-English Lexicon. 9th ed. Oxford: Clarendon Press, I996. [LSJ]

McCoy, Marina. "Socrates on Simonides: The Use of Poetry in Socratic and Platonic Rhetoric." Philosophy and Rhetoric 32 (1999): 349-67. ["Socrates on Simonides"]

Moraitou, Despina. Die Äusserungen des Aristoteles über Dichter und Dichtung ausserhalb der Poetik. Stuttgart: Teubner, I994.

${ }^{93}$ The questions of how to make the interpretation of philosophical works-especially those by leading figures in the history of philosophy_philosophical is a live one in current debates about the methodology of historiography of philosophy. See e.g. Garber, "What's Philosophical”; Kenny, "The Philosoher's History and the History of Philosophy"; Hatfield, "The History of Philosophy as Philosophy"; and Garrett, "Philosophy and History in the History of Modern Philosophy."

${ }^{94}$ On the conditions that Plato articulates in the Phdr. for philosophical writing, that is, writing aimed at provoking a philosophical response, see Trivigno, "Putting Unity in Its Place." 
Page, Denys L. Poetae Melici Graeci. Oxford: Oxford University Press, I 962.

Pappas, Nickolas. "Socrates' Charitable Treatment of Poetry." Philosophy and Literature I3 (I989): 248-6I. ["Socrates' Charitable Treatment"]

Parry, Hugh. "An Interpretation of Simonides 4 (Diehl)." Transactions and Proceedings of the American Philological Association 96 (I965): 297-320.

Partee, Henry M. "Inspiration in the Aesthetics of Plato." Journal of Aesthetics and Art Criticism 30 (I97I): 87-95.

Scodel, Ruth. "Literary Interpretation in Plato's Protagoras." Ancient Philosophy 6 (I987): 25-37. ["Literary Interpretation"]

Silk, Michael S. Aristophanes and the Definition of Comedy. Oxford: Oxford University Press, 2000.

Smyth, Herbert W. Greek Melic Poets. New York: Macmillan, I900.

Sorrell, Tom, and G. A. J. Rogers, eds. Analytic Philosophy and History of Philosophy. Oxford: Clarendon Press, 2005.

Taylor, Alfred E. Plato: The Man and His Work. 6th ed. Cleveland and New York: Meridian, I 966. [Plato]

Taylor, Christopher C. W. Plato: Protagoras. Oxford: Clarendon Press, I99I.

Tigerstedt, Eugène N. Plato's Idea of Poetical Inspiration. Helsinki: Societas Scientiarum Fennica, I969.

Trivigno, Franco V. "Etymology and the Power of Names in Plato's Cratylus." Ancient Philosophy 32 (20I 2): I-4I. ["Etymology and the Power of Names"]

."Paratragedy in Plato's Gorgias." Oxford Studies in Ancient Philosophy 36 (2009): 73-105.

. "Putting Unity in Its Place: Organic Unity in Plato's Phaedrus." Literature and Aesthetics I9 (2009): I 53-82. ["Putting Unity in Its Place"]

. "The Rhetoric of Parody in Plato's Menexenus." Philosophy and Rhetoric 42 (2009): 29-58. ["The Rhetoric of Parody"]

. "Technê, Inspiration and Comedy in Plato's Ion." Apeiron 45 (20I2): 283-3 I3. ["Technê, Inspiration and Comedy"]

Vlastos, Gregory. Plato’s Protagoras. New York: Liberal Arts Press, I 956.

. "The Socratic Elenchus." Oxford Studies in Ancient Philosophy I (I983): 27-58.

West, M. L., ed. Iambi et Elegi Graeci: Ante Alexandrum Cantati, vol. I. Oxford: Oxford University Press, I97I.

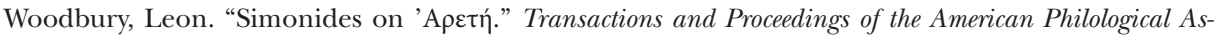
sociation 84 (I953): I35-63.

Woodruff, Paul. "What Could Go Wrong With Inspiration? Why Plato's Poets Fail." In Plato on Beauty, Wisdom and the Arts, edited by Julius Moravcsik and Philip Temko, I37-50. Lanham: Rowman and Littlefield, I982.

A B B R E V I A T I O N O F A N C I E N T S OURCES

Aristotle:

Poet.-Poetics

Met.-Metaphysics

Top.-Topics

Plato:

Ap.-Apology

Crat.-Cratylus

Euthphr.-Euthyphro

Euthd.-Euthydemus

Grg.-Gorgias

Hp. Mi.-Hippias Minor

Ly. - Lysis

Mx.-Menexenus

Phdr-Phaedrus

Prt.-Protagoras

Rep-Republic

Sextus Empiricus:

Pyrrh. Hyp.—Outlines of Pyrrhonism

Simplicius:

in Phys._Commentary on Aristotle's Physics 